\title{
The V-ATPase $a 3$ Subunit: Structure, Function and Therapeutic Potential of an Essential Biomolecule in Osteoclastic Bone Resorption
}

\author{
Anh Chu, Ralph A. Zirngibl and Morris F. Manolson*
}

check for

updates

Citation: Chu, A.; Zirngibl, R.A.; Manolson, M.F. The V-ATPase $a 3$ Subunit: Structure, Function and Therapeutic Potential of an Essential Biomolecule in Osteoclastic Bone Resorption. Int. J. Mol. Sci. 2021, 22, 6934. https://doi.org/10.3390/ ijms22136934

Academic Editors: Sophie Roux and Hugues Allard-Chamard

Received: 1 June 2021

Accepted: 21 June 2021

Published: 28 June 2021

Publisher's Note: MDPI stays neutral with regard to jurisdictional claims in published maps and institutional affiliations.

Copyright: (C) 2021 by the authors Licensee MDPI, Basel, Switzerland. This article is an open access article distributed under the terms and conditions of the Creative Commons Attribution (CC BY) license (https:// creativecommons.org/licenses/by/ $4.0 /$ )
Faculty of Dentistry, University of Toronto, Toronto, ON M5G 1G6, Canada; anhnt.chu@mail.utoronto.ca (A.C.); ralph.zirngibl@utoronto.ca (R.A.Z.)

* Correspondence: m.manolson@utoronto.ca

Abstract: This review focuses on one of the 16 proteins composing the V-ATPase complex responsible for resorbing bone: the $a 3$ subunit. The rationale for focusing on this biomolecule is that mutations in this one protein account for over $50 \%$ of osteopetrosis cases, highlighting its critical role in bone physiology. Despite its essential role in bone remodeling and its involvement in bone diseases, little is known about the way in which this subunit is targeted and regulated within osteoclasts. To this end, this review is broadened to include the three other mammalian paralogues ( $a 1, a 2$ and $a 4)$ and the two yeast orthologs (Vph1p and Stv1p). By examining the literature on all of the paralogues/orthologs of the V-ATPase $a$ subunit, we hope to provide insight into the molecular mechanisms and future research directions specific to $a 3$. This review starts with an overview on bone, highlighting the role of V-ATPases in osteoclastic bone resorption. We then cover V-ATPases in other location/functions, highlighting the roles which the four mammalian $a$ subunit paralogues might play in differential targeting and/or regulation. We review the ways in which the energy of ATP hydrolysis is converted into proton translocation, and go in depth into the diverse role of the $a$ subunit, not only in proton translocation but also in lipid binding, cell signaling and human diseases. Finally, the therapeutic implication of targeting $a 3$ specifically for bone diseases and cancer is discussed, with concluding remarks on future directions.

Keywords: V-ATPase; osteoclasts; bone; osteoporosis; osteopetrosis; anti-resorptive therapeutics; signalosome; TCIRG1; V-type proton ATPase 116 kDa subunit a3; OC-116 kDa; ATP6V0A3; ATP6V1C

\section{Bone}

Bone is a remarkable dynamic tissue which is involved in a variety of roles besides providing structural support. Bone exhibits endocrine, immune, mineral storage, growth factor, organ protection and repair functions [1-3]. Most of these functions can be attributed to the presence of three distinct major cell types, the osteoblast (OB), the osteoclast (OC) and the osteocytes. Osteoblasts are derived from mesenchymal stem cells during embryogenesis, and are responsible for the secretion of a proteinaceous matrix, including growth factors, which becomes mineralized [1,4]. OBs are found lining the bone surface and also become encased in the mineralized matrix, where they differentiate into osteocytes [5,6]. Osteocytes communicate with each other and other cell types via canaliculi found in bone. Osteocytes are capable of detecting stresses on the skeleton, and are able to activate OBs lining the bone surface, as well as OCs to start the repair process [7]. Osteoclasts have been thought to arise from hematopoietic cells exclusively; however, recent lineage tracing studies using mice have shown that there is also an extraembryonic component to this [8,9]. Cells derived from erythromyeloid-progenitors (EMP) in the embryonic yolk sac are the first wave of $O C$ to differentiate, followed later by a distinct second wave derived from hematopoietic stem cells (HSCs). These two stem cell populations occupy two different niches in the adult, with the EMP homing to the spleen while the HSCs seed 
the bone marrow $[8,9]$. OCs are capable of resorbing bone via their ability to secrete acid to dissolve the mineral component and proteinases in order to digest the now exposed proteinaceous matrix $[10,11]$. This is a highly organized process that involves pre-OC cells fusing with each other, the formation of a sealed bone compartment underneath the now multinucleated OC sequestered by the sealing zone, and the formation of a ruffled membrane contained within the sealing zone [12-14]. The ruffled border acts as the gateway for the secretion of the acid and proteinases, and allows for the uptake of the dissolved mineral and digested proteins, which are mostly transcytosed by vesicles to the apical cell membrane for eventual disposal via the circulation [15]. Experiments performed in RAW 264 cells showed that the formation of an actin ring redirects intracellular vesicles, mostly secretory lysosomes, to transport large quantities of proteinases (e.g., Cathepsin K, alkaline phosphatase) and the acid generating machinery (made up from chloride channel 7 and the V-ATPase) to the OC plasma membrane adjacent to the bone surface [16,17]. Bone remodeling is a highly coordinated process that involves constant communication between OBs and OCs, and any interference with this can lead to disease $[10,18,19]$. V-ATPases are involved in pre-pro-protein processing (including glycosylation) [20], secretion [21], the internalization and degradation of molecules [22], vesicle transport and fusion [23,24], modulate signaling complexes, participate in distinct signalosomes [25], and promote cell migration in cancer [26]. To this end, mutations that interfere with V-ATPase function underlie diseases affecting a number of organ systems.

\section{V-ATPase Functions}

V-ATPases are ATP-driven proton pumps found in the endomembrane of the intracellular compartments in all of the eukaryotic cells and the plasma membrane of several specialized cells [27]. V-ATPases are responsible for acidifying and maintaining the $\mathrm{pH}$ of intracellular organelles, including the Golgi apparatus, endosome, lysosome and secretory vesicles $[28,29]$. V-ATPases pump protons into the Golgi apparatus, which become more acidic from the cis-Golgi to the trans-Golgi [20]. As newly synthesized proteins traverse the Golgi apparatus, they undergo post-translational modification including glycosylation, sulfation and phosphorylation. The maintenance of the $\mathrm{pH}$ gradient in the Golgi apparatus by V-ATPases is crucial for the function and localization of the glycosyltransferases required for the modification processes [30]. V-ATPase activity in the intracellular membrane is important for membrane trafficking processes such as receptor-mediated endocytosis [21,22]. The V-ATPase-dependent acidification of the endocytic compartments is required for the dissociation of ligand-receptor complexes, allowing the receptors to recycle to the cell surface. The released ligands are subsequently targeted to the lysosomes, where the low $\mathrm{pH}$ maintained by V-ATPases facilitates their degradation [31,32]. This process is important for the continued uptake of ligands such as low-density lipoprotein (LDL), a main carrier of plasma membrane cholesterol [33]. Many pathogens employ the V-ATPase-mediated acidification of the endocytic compartments to gain entry into cells, including diphtheria and anthrax toxins, as well as viruses such as influenza and Ebola [34,35]. After entering the host cells, viruses also require a low $\mathrm{pH}$ to trigger fusion and to deliver their viral genome into the host. V-ATPases are also involved in the intracellular trafficking of lysosomal enzymes by establishing a luminal $\mathrm{pH}$ gradient between compartments [21,32]. Lysosomes are more acidic than late endosomes, which in turn are more acidic than the trans-Golgi network (TGN). This gradient allows the binding of lysosomal proteases to the mannose-6-phosphate receptor at the TGN, facilitating the enzyme delivery to the lysosomes, and the dissociation of enzyme-receptor complexes in late endosomes, allowing the receptors to recycle to the TGN [36]. V-ATPases play a key role in cellular nutrient homeostasis by providing the acidic environment within lysosomes which is necessary for proteolysis, which is a major way in which cells generate free amino acids [37-39]. In addition to maintaining the lysosomal $\mathrm{pH}, \mathrm{V}$-ATPases also associate with the nutrient-sensing machinery in the lysosomal membrane, and are involved in the recruitment of the metabolic regulators mTORC1 and AMPK [38-40]. Within secretory vesicles, 
V-ATPases generate a proton gradient driving the uptake of small molecules such as the neurotransmitter glutamate [41-43], and they facilitate the processing of prohormones like proinsulin $[33,44,45]$.

V-ATPases are targeted to the plasma membrane of specialized cells such as kidney intercalated cells [46,47], epididymis clear cells $[48,49]$ and osteoclasts $[50,51]$, where they function to transport protons from the cytoplasm to the extracellular space [30,52-54]. In the kidneys, V-ATPases are localized to the apical membrane of the alpha-intercalated cells to facilitate the secretion of protons into the urine in order to maintain $\mathrm{pH}$ homeostasis [54]. Osteoclasts rely on V-ATPases at the ruffle border for the demineralization of bone and the activation of the proteolytic enzymes required for bone resorption $[55,56]$. V-ATPases targeting the plasma membrane of epididymis clear cells are involved in the establishment of the acidic luminal $\mathrm{pH}$ necessary for sperm maturation and storage [49]. Recently, plasma membrane V-ATPases have been shown to be overexpressed in breast cancer cells, and to facilitate invasion by promoting the activity of acid-dependent proteases that degrade the extracellular matrix [57]. The inhibition of V-ATPases by concanamycin in prostate cancer cells results in a decreased level of mRNA for prostate-specific antigens [58]. Increasing evidence implicates the important role of V-ATPases in cancer cells' growth and metastasis, and suggests a potential therapeutic treatment of metastatic cancer by the inhibition of V-ATPases activity.

In addition to the conventional functions of V-ATPases in intracellular signalling and membrane trafficking by generating $\mathrm{pH}$ gradients, recent findings suggest novel emerging roles of V-ATPases in the modulation of the function of receptors and their regulatory complexes through direct protein-protein interactions. For example, it was recently uncovered that Wnt/ $\beta$-catenin signal transmission requires the interaction of co-receptor LRP6 with V-ATPase lysosomal accessory protein-2 (ATP6AP2) in late endosomes [59]. In Drosophila, V-ATPases have been suggested to be involved in the membrane fusion of synaptic vesicles via direct interaction with calmodulin [60]. Emerging studies propose the importance of V-ATPases in modulating various signalling pathways, including Notch, mTOR and AMPK via unconventional mechanisms $[39,61]$.

In summary, V-ATPase-dependent acidification is essential for cellular metabolism, membrane trafficking and intracellular signalling. Moreover, the importance and novel emerging roles of V-ATPases in many signalling pathways and diseases, including cancers, makes them promising targets for drug development.

\section{V-ATPase Structure}

V-ATPases share their structure with mitochondrial and chloroplast F-type ATPases [27]. Both enzymes are composed of a peripheral catalytic sector $\left(V_{1}\right.$ or $\left.F_{1}\right)$ and a membranebound proton channel sector $\left(\mathrm{V}_{\mathrm{O}}\right.$ or $\left.\mathrm{F}_{\mathrm{O}}\right)$. They are evolutionarily related, and are functionally conserved as rotary proton pumps [44]. The eukaryotic V-ATPase is a $900 \mathrm{kDa}$ complex consisting of sixteen subunits: $\mathrm{A}_{3} \mathrm{~B}_{3} \mathrm{CDE}_{3} \mathrm{FG}_{3} \mathrm{H}$ comprising the $\mathrm{V}_{1}$ sector, and ${ }_{a c}{ }_{9} c^{\prime \prime} \operatorname{def} \mathrm{AP} 1 \mathrm{AP} 2$ forming the membrane-bound $\mathrm{V}_{\mathrm{O}}$ (the subscript numbers represent the subunits' stoichiometry in the complex) (Figure 1) [62,63]. Subunits A and B are arranged in a hexameric configuration and contain the nucleotide binding sites responsible for ATP hydrolysis [64]. ATP hydrolysis creates a driving force to induce the rotation of the central stalk composed of subunits $\mathrm{D}, \mathrm{F}$ and $d$, and the membrane-bound proteolipid $c$-ring ${ }_{9} c^{\prime \prime}[65]$.

Each proteolipid subunit $c, c^{\prime \prime}$ has a conserved glutamate residue which is essential for proton translocation (E139 in $c$, and E98 in $c^{\prime \prime}$ ) $[64,66,67]$. The glutamate residues are protonated when the subunit rotates past the membrane-embedded C-terminal domain of the $a$ subunit $\left(a_{\mathrm{CT}}\right)$. The $a_{\mathrm{CT}}$ forms two half-channels that create a pathway for protons to cross from cytoplasm to the organellar lumen or the extracellular space [64]. Protons access the glutamate residue of subunit $c$ upon entering the cytosolic half-channel, and the protonated glutamate residue carries the proton through the lipid bilayer as the $c$-ring rotates. The proton is released through the luminal half-channel following the deprotona- 
tion of the glutamate residue and stabilization by the critical arginine residue R740 in the $a$ subunit (R735 in Vph1p, an S. cerevisiae ortholog of the $a$ subunit) [68]. The AB hexamer is held stationary relative to the $a$ subunit by three peripheral stalk EG heterodimers which connect the $\mathrm{V}_{1}$ sector to subunits $\mathrm{C}$ and $\mathrm{H}$, and the $\mathrm{N}$-terminal domain of the $a$ subunit $\left(a_{\mathrm{NT}}\right)[69]$.

V-ATPase activity is tightly controlled both spatially and temporally. One example of the temporal modes of V-ATPase regulation is the reversible assembly/disassembly upon environmental cues, which was first described in yeast [70]. The dissociation of $V_{1}-V_{O}$ sectors is regulated by nutrient availability, as the dissociated complex is inactive in both ATP hydrolysis and proton translocation, reflecting the cells' attempt to conserve cellular ATP. In yeast, the dissociation occurs in response to glucose starvation, involves an intact microtubular network, and is reversible without new protein synthesis [71]. Upon $V_{1}-V_{O}$ disassembly, the $\mathrm{C}$ subunit dissociates from the V-ATPase complex, and the $\mathrm{H}$ subunit undergoes a conformational change resulting in the loss of the interaction with $a_{\mathrm{NT}}$ [72]. The reassembly of the complex requires the RAVE complex (Rav1, Rav2 and Skp1). The RAVE complex binds to subunits $E$ and $G$, the dissociated $C$ subunit of $V_{1}$, and to the $\mathrm{V}_{\mathrm{O}}$ subunit $a$, thereby positioning them to promote assembly [70]. The glucose-induced reassembly of V-ATPases requires the interaction of the protein complexes with regulatory proteins, such as the RAVE complex. Moreover, studies in yeast and RAW 264 osteoclastlike cells suggest a direct interaction between the glycolytic enzyme aldolase and V-ATPase subunits in a glucose-dependent manner [73]. The deletion of the aldolase gene in yeast resulted in V-ATPase disassembly and a reduction in V-ATPase activity [74]. In the presence of glucose, aldolase and V-ATPase interactions increase, inducing the reassembly of $V_{1}$ and $\mathrm{V}_{\mathrm{O}}$; hence, aldolase can act as a glucose sensor mediating V-ATPase assembly [75]. Several other determinants of V-ATPase assembly have been identified, including the membrane environment [76] and the interaction with regulatory factors such as HRG-1 [77] and viral infection [34]. The spatial regulation of V-ATPases is observed in the luminal $\mathrm{pH}$ gradients between compartments [78,79]. This mechanism of controlling V-ATPase activity is through the regulation of the trafficking of the complex, which is facilitated by different isoforms of the $a$ subunit $[80,81]$. 


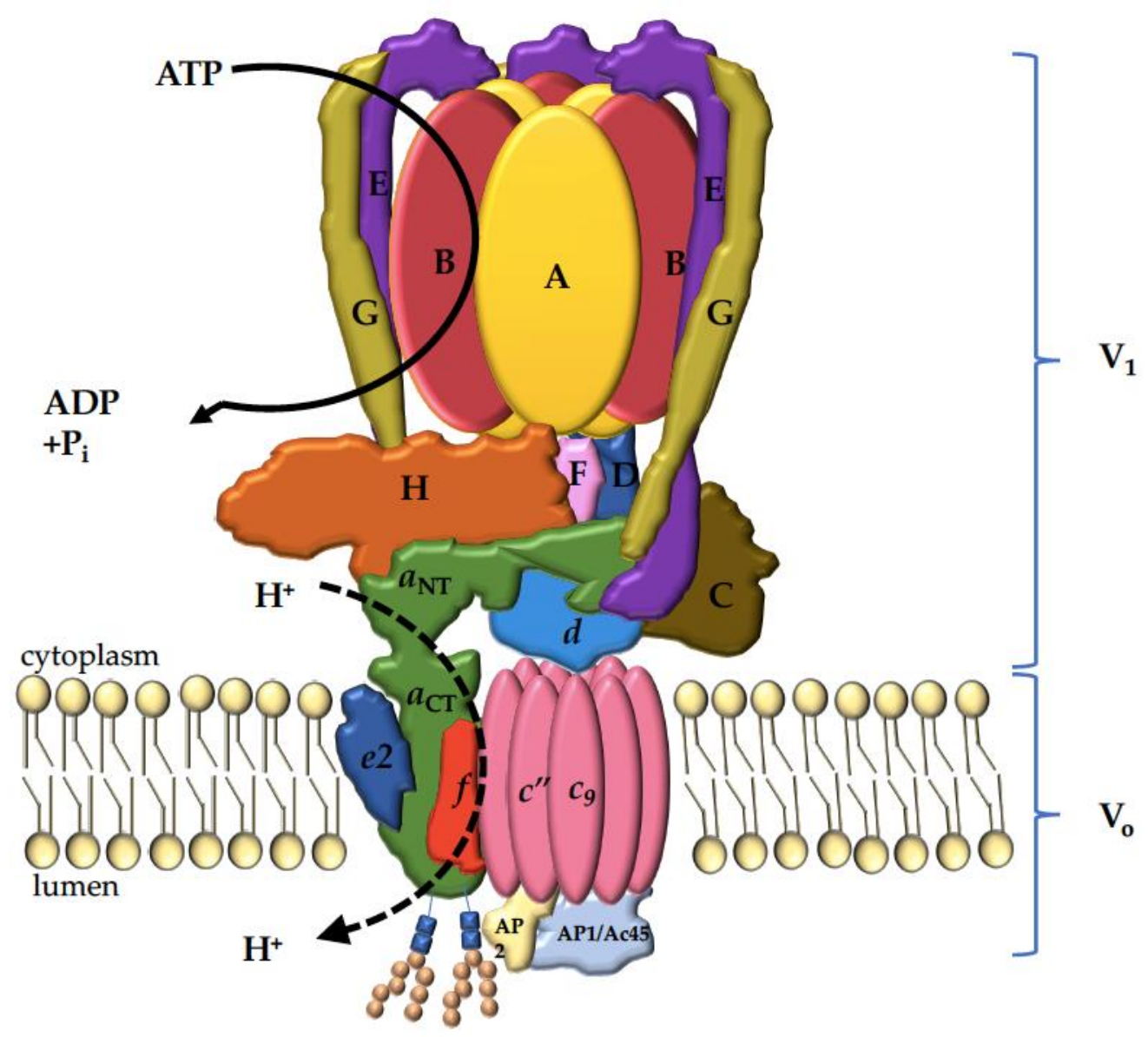

Figure 1. Mammalian V-ATPase complex. Cytosolic sector $\mathrm{V}_{1}$, comprised of $\mathrm{A}_{3} \mathrm{~B}_{3} \mathrm{CDE}_{3} \mathrm{FG}_{3} \mathrm{H}$, is responsible for the ATP hydrolysis, which generates the force required to drive the rotation of the proteolipid $c$-ring $\left(c_{9} c^{\prime \prime}\right)$ of the membrane-bound $\mathrm{V}_{\mathrm{O}}$ consisting of $a c_{9} c^{\prime \prime}$ def AP1AP2. The $a_{\mathrm{CT}}$ forms two half-channels that create a pathway for protons to cross the lipid bilayer as the $c$-ring rotates. Both $a 2$ and $a 3$ orthologs are glycosylated twice on the first luminal loop within the C-terminus (depicted here), whereas $a 1$ and $a 4$ are only glycosylated once [82].

\section{The V-ATPase $a$ Subunit}

Each V-ATPase complex contains one copy of the $\sim 100 \mathrm{kDa} a$ subunit, which exists as two isoforms in yeast (Vph1p and Stv1p) and four isoforms (a1, a2, a3 and $a 4)$ in mammals $[27,80,83]$. The $a$ subunit has a bipartite structure, with a cytoplasmic $\mathrm{N}$-terminal half $\left(a_{\mathrm{NT}}\right)$ and a membrane-integrated C-terminal half $\left(a_{\mathrm{CT}}\right)$ which consists of eight transmembrane helices (Figure 2) [62,84]. As described above, two of the eight helices in $a_{\mathrm{CT}}$ are tilted and interact with the proteolipid $c$-ring to form the two hemichannels for proton translocation [62,85]. Even though ATP hydrolysis-coupled proton translocation can tolerate numerous $a$ subunit mutations, the arginine residue in $a_{\mathrm{CT}}$ (R735 in Vph1p, and R740 in TCIRG1 encoding the mammalian $a 3$ isoform) is absolutely essential [68]. The dominant R740S missense mutation of this critical arginine in mice uncouples the proton pumping activity from ATP hydrolysis, resulting in mice with a high bone mineral density [86]. The $a_{\mathrm{NT}}$, oriented parallel to the membrane, is essential for V-ATPase function as it couples $\mathrm{V}_{1}$ ATP hydrolysis to $\mathrm{V}_{\mathrm{O}}$ proton translocation [44]. 


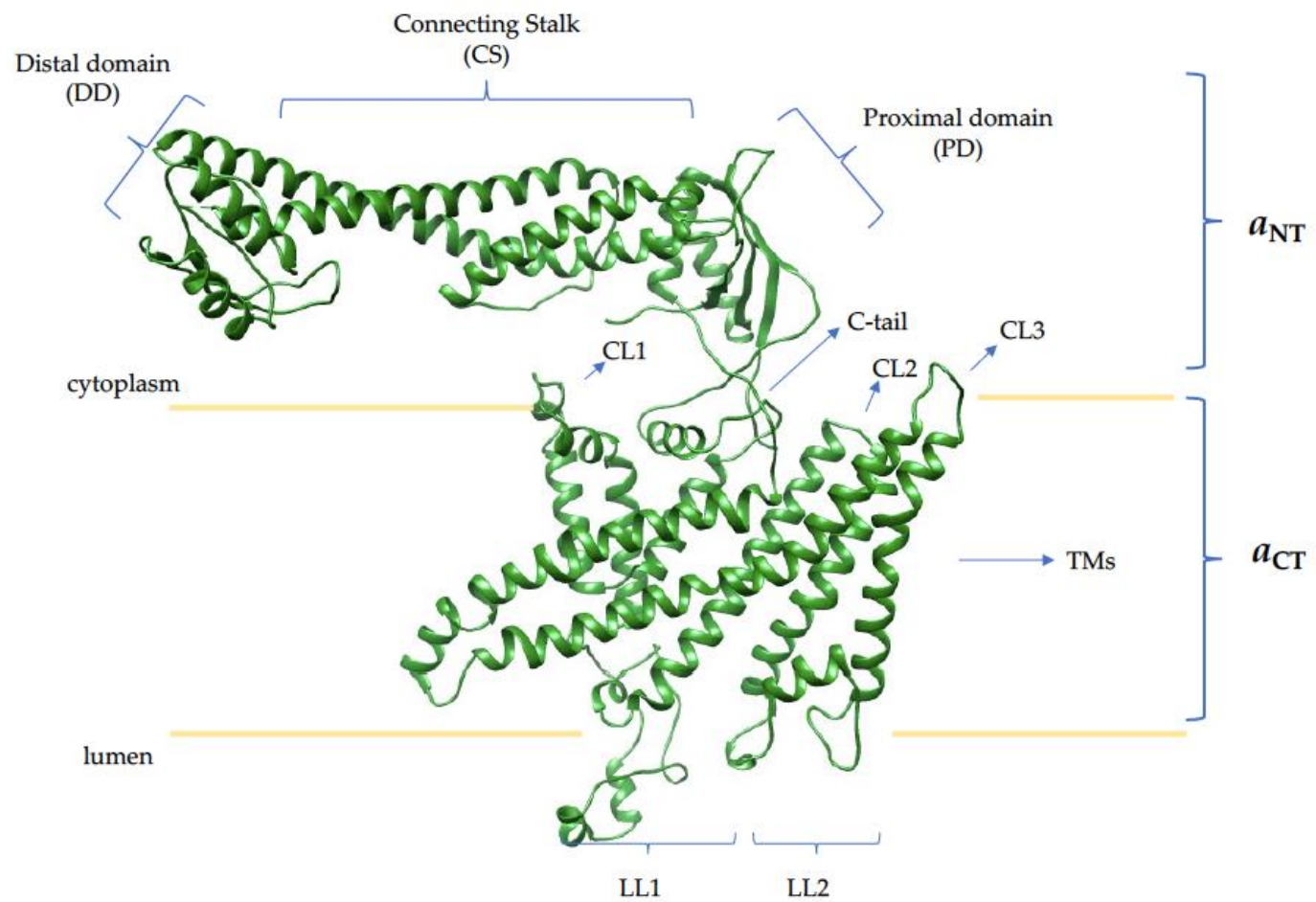

(a)

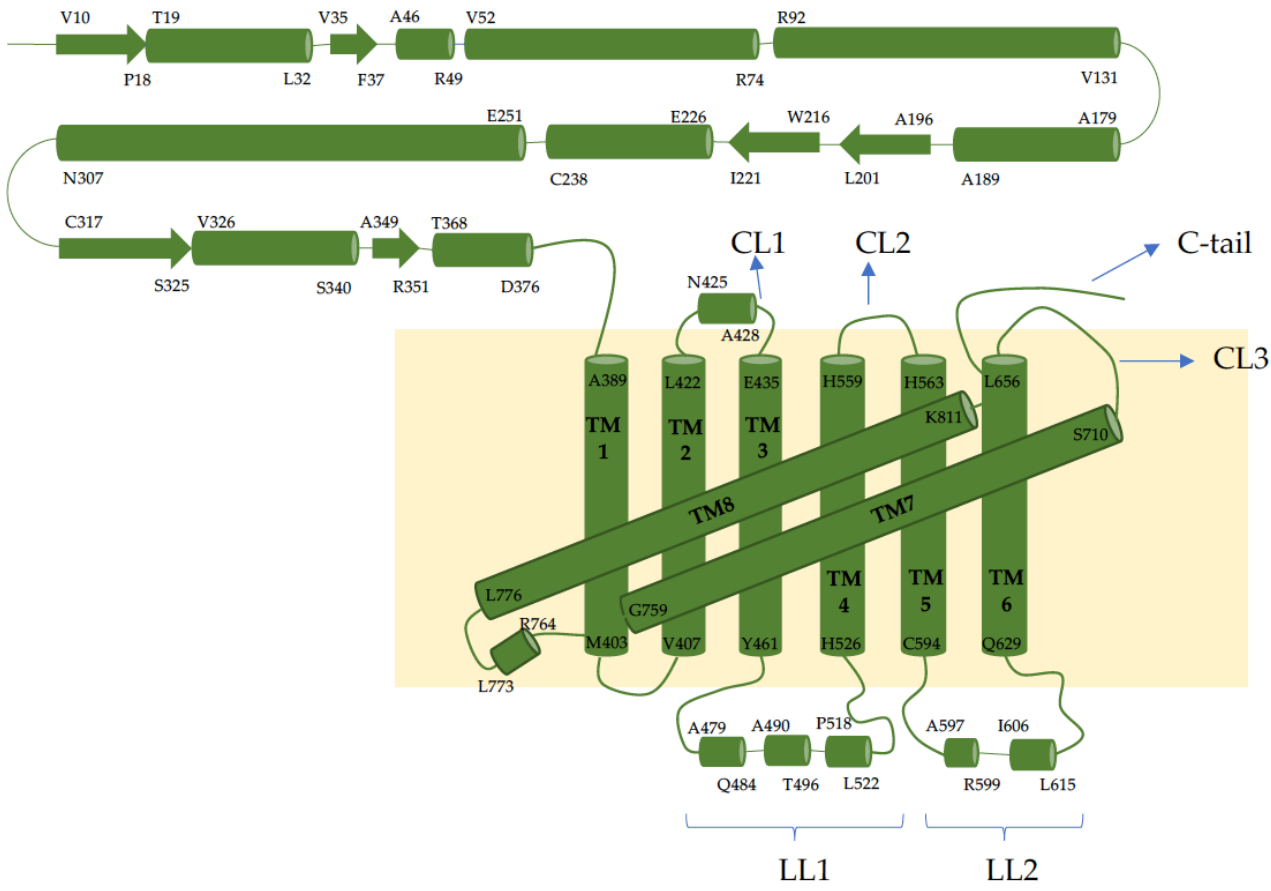

(b)

Figure 2. Mammalian V-ATPase $a 3$ subunit. (a) Homology model of the $a 3$ isoform generated using the Phyre2.0 server with constraint coordinates from the mammalian brain $a 1$ isoform (PDB: 6vqc_3); (b) topology of the $a 3$ isoform. The a subunit contains a cytoplasmic N-terminal half $\left(a_{\mathrm{NT}}\right)$, which can be divided into three sub-domains-a distal domain (DD), connecting stalk (CS) and a proximal domain (PD)_-and a membrane-bound C-terminal half $\left(a_{\mathrm{CT}}\right)$ consisting of eight transmembrane helices (TM1-8), two of which are tilted and form the two hemichannels with the proteolipid $c$-ring. Cytosolic loops (CL1-3) connect TM2 and 3, TM4 and 5, and TM6 and 7, respectively; luminal loops 1 and 2 (LL1 and LL2) connect TM3 and 4, and TM5 and 6, respectively. Within luminal loop 1, $a 2$ and $a 3$ orthologs are glycosylated twice, whereas $a 1$ and $a 4$ are glycosylated once [82]. 
Studies with chimeric forms of Vph1p and Stv1p suggest that organelle targeting information is located in $a_{\mathrm{NT}}$ [87]. In yeast, V-ATPases are targeted to the vacuole and Golgi by Vph1p and Stv1p, respectively; when chimeric $a$ subunits were made, the targeted organelles were determined by the $a_{\mathrm{NT}}$. Furthermore, mutagenesis studies revealed that the signal sequence $\mathrm{W}^{83} \mathrm{KY}$ within the $a_{\mathrm{NT}}$ of Stv1p is necessary for V-ATPase Golgi localization [88].

Similarly, in mammalian cells, different isoforms of the $a$ subunit are enriched in specific organelles or cell types. However, the specific targeting signal of mammalian $a$ isoforms has not been determined. V-ATPases containing the $a 1$ isoform are found in the synaptic vesicles of neurons, and are relocated to the presynaptic plasma membrane at the nerve terminals [60,89]. The $a 2$ isoform targets Golgi [90], and the $a 3$ isoform is expressed in late endosomes and lysosome [16,91]. The $a 3$ and $a 4$ isoforms are also found on the plasma membrane of specialized cells, with $a 3$ targeting the ruffle border of osteoclasts [50,92]; $a 4$ is found in the apical membrane of kidney alpha intercalated cells and epididymal cells $[49,93]$. The upregulation of both $a 3$ and $a 4$ have been linked to the invasiveness of metastatic breast cancer cells [26]. Recently, the $a 4$ isoform was shown to localize to the membrane of the invapodia of mouse breast cancer cells, where it plays a crucial role in the invasion and migration of the cancer cells [94]. While it is ubiquitously expressed in different organelles and cell types, the expression of $a 3$ is approximately 100 -fold greater in osteoclasts than in other cell types [95]. V-ATPases containing $a 3$ are enriched in the membrane of the ruffled border, where they actively pump acid to dissolve bone and provide an acidic environment to activate the secreted proteases required for bone resorption. Furthermore, mutations in the $a 3$ isoform in mammals-for example, the R740S in mice, mentioned above [86] — are associated with V-ATPase-related autosomal recessive osteopetrosis $[53,96,97]$. To this end, it is clear that the $a 3$ isoform plays a crucial role in bone resorption by osteoclasts; therefore, the $a 3$ isoform is a potential drug target for osteoporosis treatment, in which the excessive bone loss associated with this disease could be controlled by inhibiting $a 3$-containing V-ATPases $[50,98,99]$.

\section{5. $a 3-d 2-\mathrm{B} 2$}

Consistent with their diverse roles in intracellular compartments and different cell types, mammalian V-ATPase subunits have a variety of isoforms. Seven subunits have two to four isoforms, and the combination of different subunit isoforms are organelle- and tissue-specific $[46,49,100,101]$. For examples, the combination of $a 3, d 2$ and B2 is specific for osteoclasts $[92,102,103]$. Both $a 3$ and B2 are highly expressed in the plasma membrane of osteoclasts [103], and studies in RANKL-differentiated RAW 264.7 cells indicate that $a 3$ has a higher affinity for B2 than B1, and the inhibition of the a3-B2 interaction by the KM9114 compound may inhibit the resorptive activity of osteoclasts [55]. The $d 2$ subunit has been found in various tissues, but is most abundant in osteoclasts [104], and a GST pull-down assay suggests a high-affinity interaction between $a 3$ and $d 2$ [102]. The RNAi knockdown of $d 2$ resulted in the impairment of extracellular acidification by osteoclasts [105].

\section{Human Diseases Linked to V-ATPase Mutations}

As many biological processes are dependent on proton gradients, it is not surprising that close to half of the V-ATPase subunits are associated with human diseases; they are summarized in Table 1. While many disease-causing mutations within V-ATPase subunits have been identified, the precise molecular mechanisms underlying the ways in which mutations cause defects is generally not known. This is predominantly due to the lack of analysis other than reports of the mutations provided. Some mutations can be reconciled as null mutations (i.e., frame shifts, splice donor/acceptor mutations); however, most of these have not been experimentally demonstrated and rely heavily on computer prediction programs. For this review, we will restrict the discussion to mutations in the $a$ subunit, with some general conclusions reached which are specific to this subunit. 
Table 1. Summary of V-ATPase subunit nomenclature, gene designation and associated human diseases.

\begin{tabular}{|c|c|c|c|c|}
\hline Subunit Designation a & Yeast Gene ${ }^{b}$ & Human Gene ${ }^{b}$ & Function & Human Disease (OMIM\#) ${ }^{c}$ \\
\hline \multicolumn{5}{|c|}{$\mathrm{V}_{1}$ Subunits } \\
\hline A & VMA1 & ATP6V1A & ATP binding/hydrolysis & $\begin{array}{c}\text { \#617403-Cutis laxa, type IID (AR) \#618012 } \\
\text { Developmental and epileptic encephalopathy } 93 \text { (AD) }\end{array}$ \\
\hline \multirow[b]{2}{*}{ B } & \multirow[b]{2}{*}{ VMA2 } & ATP6V1B1 & \multirow[b]{2}{*}{ ATP binding/hydrolysis } & $\begin{array}{l}\text { \# 267300-Renal tubular acidosis, distal, with } \\
\text { progressive nerve deafness (AR) }\end{array}$ \\
\hline & & ATP6V1B2 & & $\begin{array}{l}\text { \# 124480-Deafness, congenital, with onychodystrophy; } \\
\text { DDOD (AD) } \\
\text { \# 616455-Zimmermann-Laband syndrome 2; } \\
\text { ZLS2 (AD) }\end{array}$ \\
\hline \multirow{3}{*}{ C } & \multirow{3}{*}{ VMA5 } & ATP6V1C1 & & \\
\hline & & ATP6V1C2 & & Recessive renal tubular acidosis [106] \\
\hline & & ATP6V1C3 & & \\
\hline $\mathrm{D}$ & VMA6 & ATP6V1D & Torque transmission & \\
\hline $\mathrm{E}$ & VMA4 & ATP6V1E1 & Stator function & \# 617402-Cutis laxa, type IIC; ARCL2C (AR) \\
\hline $\mathrm{F}$ & VMA7 & ATP6V1F & Torque transmission & \\
\hline \multirow{3}{*}{ G } & \multirow{3}{*}{ VMA10 } & ATP6V1G1 & \multirow{3}{*}{ Stator function } & \\
\hline & & ATP6V1G2 & & \\
\hline & & ATP6V1G3 & & \\
\hline \multirow[t]{2}{*}{$\mathrm{H}$} & VMA13 & ATP6V1H & & \\
\hline & \multicolumn{3}{|c|}{$\mathrm{V}_{\mathrm{O}}$ Subunit } & \\
\hline \multirow{4}{*}{$\mathrm{a}$} & \multirow{4}{*}{ VPH1/STV1 } & ATP6V0A1 & \multirow{4}{*}{ Stator function, proton transport } & Developmental and epileptic encephalopathy [107] \\
\hline & & ATP6V0A2 & & $\begin{array}{l}\text { \# 219200-Cutis laxa, type IIA; ARCL2A(AR) } \\
\text { \# 278250-Wrinkly skin syndrome; WSS (AR) }\end{array}$ \\
\hline & & TCIRG1 & & \# 259700-Osteopetrosis, type B1; OPTB1 (AR) \\
\hline & & ATP6V0A4 & & \# 602722-Renal tubular acidosis, distal; RTADR (AR) \\
\hline
\end{tabular}


Table 1. Cont.

\begin{tabular}{|c|c|c|c|c|}
\hline Subunit Designation ${ }^{a}$ & Yeast Gene ${ }^{b}$ & Human Gene ${ }^{b}$ & Function & Human Disease (OMIM\#) ${ }^{c}$ \\
\hline c & VMA3 & ATP6V0C & \multirow{2}{*}{ Rotation, proton transport } & \\
\hline$C^{\prime}$ & VMA11 & & & \\
\hline \multirow{2}{*}{ d } & \multirow{2}{*}{ VMA6 } & ATP6V0D1 & \multirow{2}{*}{$\begin{array}{l}\text { Transmission of torque, } \\
\text { coupling ratio }\end{array}$} & \\
\hline & & ATP6V0D2 & & \\
\hline \multirow{2}{*}{ e } & \multirow{2}{*}{ VMA9 } & ATP6V0E1 & & \\
\hline & & ATP6V0E2 & & \\
\hline f & YPR170W-B & RNASEK & & \\
\hline Ac45 & VOA1 & ATP6AP1 & $\mathrm{V}_{\mathrm{O}}$ assembly & \# 300972-Immunodeficiency 47; IMD47 (XLR) \\
\hline \multirow[t]{2}{*}{ M8-9 } & & ATP6AP2 & $\mathrm{V}_{\mathrm{O}}$ assembly & $\begin{array}{l}\text { \# 301045-Congenital disorder of glycosylation, type IIr; } \\
\text { CDG2R (XLR) } \\
\text { \# 300423-Mental retardation, X-linked, syndromic, } \\
\text { hedera type; MRXSH (XLR) } \\
\text { \# 300911-Parkinsonism with spasticity, X-linked; } \\
\text { XPDS (XLR) }\end{array}$ \\
\hline & \multicolumn{3}{|c|}{ Chaperone } & \\
\hline \multirow[t]{3}{*}{ VMA12 } & VPH2 & TMEM199 & Stabilizes Vph1p, binds Vma22p & $\begin{array}{l}\text { \# 616829-Congenital disorder of glycosylation, type IIp; } \\
\text { CDG2P (AR) }\end{array}$ \\
\hline & VMA21 & VMA21 & $\begin{array}{l}\text { Assembles } \mathrm{V}_{\mathrm{O}} \text {, exports } \mathrm{V}_{\mathrm{O}} \text { from } \mathrm{ER} \\
\text { to Golgi }\end{array}$ & $\begin{array}{l}\text { \# 310440-myopathy, X-linked, with excessive } \\
\text { autophagy; MEAX (XLR) }\end{array}$ \\
\hline & VMA22 & CCDC115 & Stabilizes Vph1p, binds Vma12p & $\begin{array}{l}\text { \# 616828-Congenital disorder of glycosylation, type IIo; } \\
\text { CDG2O (AR) }\end{array}$ \\
\hline
\end{tabular}

${ }^{a}$ Historical subunit designation; ${ }^{b}$ official gene symbol http:/ncbi.nlm.nih.gov/gene (May 2021); ${ }^{\mathrm{c}}$ online Medelian inheritance in man (OMIM) http:/www.omim.org (May 2021). 
First, most $a$ subunit mutations are recessive, with a single wildtype gene being sufficient for V-ATPase function. For example, carrier parents with heterozygous mutations have no obvious phenotype, indicating that $50 \%$ gene expression is sufficient; the caveat to this statement is that reports on human $a 3$ mutations rarely, if ever, thoroughly examine the heterozygous parents $[97,108-110]$.

With respect to protein expression, patients with only $5-10 \%$ wildtype $a 3$ protein expression can progress past the infantile mortality normally associated with $a 3$ mutations; however, these patients still present with osteopetrosis, as well as vision and hearing loss $[97,111,112]$. Nevertheless, while dominant negative $a 3$ mutations have not been identified in humans, our lab identified one example in mice; an R740S point mutation resulted in osteopetrotic mice in heterozygotes and early lethality in homozygotes. R740 is critical for proton translocation but not for folding, stability, or assembly. The a3_R740S protein is assembled into a complex and translocated to the OC ruffled border, but this results in an uncoupled enzyme with limited ATP hydrolysis and no proton translocation activity. These inactive V-ATPases displace active complexes, leading to the dominant negative phenotype $[86,113]$.

While the R740S mutation is an example of a point mutation resulting in an assembled but inactive complex, it is more often the case that point mutations result in unstable and rapidly degraded $a$ subunits $[30,114,115]$. One caveat to this general conclusion is that mutant protein stability is general assessed in in vitro cell culture systems, and the results for single mutations vary depending on the cell type and the presence/absence of endogenous protein. For example, it was shown that $a 3$ point mutations with low expression levels in a3-null osteoclasts had wild-type expression in HEK293T cells [116].

Finally, V-ATPase-related diseases highlight specific cell types or cellular functions that are exquisitely dependent on specific isoforms, of which the function can't be compensated for by the other paralogues, even if they are present in that cell [117]. This cell and/or organelle-specific dependence may be related to expression levels. For example, in yeast, where Vph1p is expressed at about 50 times the level of Stv1p, the absence of Vph1p results in a vacuolar $\mathrm{pH}$ defect despite the presence of Stv1p, but can be complemented by the overexpression of Stv1p [83]; this indicates that while isoforms can enzymatically complement each other, their expression levels must be adjusted accordingly in order to correct a phenotype. Similarly, in osteoclasts, the $a 3$ expression is increased 100 -fold during osteoclastogenesis. While $a 1$ and $a 2$ are expressed in osteoclasts, their expression levels cannot compensate for the absence of the highly expressed a3, hence the osteopetrotic phenotype. In intercalated kidney cells, B1, $\mathrm{C} 1$ and $a 4$ subunits are highly expressed, with mutations in these isoforms resulting in renal tubular acidosis. In contrast, $a 2$ is ubiquitously expressed in all cells, but is retained within Golgi. The cutis laxa phenotype resulting from $a 2$ mutations suggests that while $a 1$ and $a 3$ expression may be equal to or exceed that of $a 2$, their inability to be retained within Golgi is the limiting factor.

\section{Membrane Signaling Lipids as Regulators of V-ATPase Localization and/or Activity}

There is increasing evidence for the involvement of membrane-signaling lipids in V-ATPase regulation [76]. In yeast, a direct interaction between Vph1p, Stv1p and different membrane phosphoinositides (PIPs) has been shown, and was hypothesized to affect V-ATPase localization. Vph1p $a_{\mathrm{NT}}$ has been shown to interact with vacuolar membrane phosphoinositide $\mathrm{PI}(3,5) \mathrm{P}_{2}$ in vitro; in the absence of $\mathrm{PI}(3,5) \mathrm{P}_{2}, \mathrm{Vph} 1 \mathrm{p}$ fails to localize to vacuoles [118]. On the other hand, Golgi-specific PI(4)P interacts with Stv1p $a_{\mathrm{NT}}$ to recruit Stv1p-containing V-ATPases to the Golgi, and enhances the activity of Golgi VATPases [119]. The Cryo-EM structure of $\mathrm{V}_{O}$ with Vph1p and Stv1p suggests binding sites for glycerophospholipids in both complexes [120]. These structural and biochemical studies suggest important roles for membrane lipids in V-ATPase function and a potential target for the modulation of its activity. The questions of whether human isoforms interact with PIPs, and whether such interaction affects the differential subcellular membrane distributions of V-ATPases in mammalian cells have not yet been determined. 


\section{V-ATPase as a Signalsome}

As discussed above, V-ATPases are localized to numerous subcellular compartments with activities regulated to match the specific needs of each destination; how this destinationspecific regulation is achieved is currently unknown, but details are emerging. Most V-ATPase localization studies have focused on the $a$ subunit. However, another way to control V-ATPase subcellular localization is via the phosphorylation of the subunits [121]. In kidney cells, activation of PKA resulted in the phosphorylation of the Ser175 of the A subunit, which altered both V-ATPase subcellular localization and activity; in contrast, the phosphorylation of Ser384 by AMPK reduced the V-ATPase activity [122]. The direct binding of PKA or AMPK to any of the V-ATPase subunits has not been demonstrated. However, it has been shown that activated pPI3K, pAKT and pERK associate with the E subunit during virus replication [123-125]. A quick search through the PhosphoSitePlus database (phosphosite.org), a curated site for phosphorylation and ubiquitylation sites identified by high throughput mass spec analysis, revealed that all of the V-ATPase subunits are modified. Thus, there are clear indications that V-ATPases can bind various kinases, and that their activity/location is controlled by phosphorylation events.

Cellular compartments can be specified depending on which small guanine nucleotide binding protein is present on the membrane. The Rab subfamily is the largest, comprised of at least 60 different proteins. Rab proteins act as molecular switches, being 'on' in their GTPbound form and able to bind effector proteins, and 'off' in their GDP-bound state [126,127]. This activity is controlled by two families of regulators, the Guanine Exchange Factor (GEF) that exchanges GDP for GTP, and Guanine Activating Protein (GAP), which activates the low intrinsic catalytic activity to promote GTP hydrolysis. a3 can bind to several Rab proteins directly in their GDP state, such as Rab7 (endosome, lysosome) and Rab27a [91]. This interaction has been mapped to the distal domain (Figure 2) in $a 3_{\mathrm{NT}}$. This allows the a3 subunit to be relocated from the late endosome to the lysosome, and eventually to the ruffled border. Whether the other $a$ subunit isoforms show distinct binding preferences for different Rab proteins has not been determined. The $a 2$ subunit has also been demonstrated to inhibit Cytohesin2, the GEF for the Arf family of small GTPases, in a pH dependent manner. This function has been mapped to the N-terminus of $a 2$, and is conserved in all of the isoforms of the $a$ subunit [128]. This would allow V-ATPases to regulate subcellular trafficking by binding to small GTPases and potentially regulating GEF activity. Other GEFs which can be influenced by V-ATPases are Ragulator and Slc38A9, the GEFs for the Rag GTPases, which bring mTORC1 to the lysosome and activate it $[129,130]$. The mechanism of regulation may involve a direct interaction with $d 1$ and the A/B subunit of active VATPases [39]. However, the detail mechanism is not yet understood. There are promising indications that mTOR may phosphorylate and regulate V-ATPase activity $[37,39]$, but further investigation is required.

\section{The Potential of $a 3$ as a Therapeutic Target for Osteolytic Diseases}

An advantage of targeting the V-ATPase $a 3$ subunit to prevent osteolytic diseases is that osteoclast differentiation and fusion is unaffected by the absence of $a 3$, as evidenced by the fact that, to date, all $a 3$ mutations have resulted in osteoclast-rich osteopetrosis [96,131-133] (Figure 3, Table 2). The gold standard anti-resorptive treatments, bisphosphonates and anti-RANKL therapy, inhibit bone resorption by preventing osteoclast formation and/or triggering osteoclast apoptosis. While both are effective anti-resorptives, the resulting decrease in osteoclast numbers reduces osteoclast-osteoblast cell signaling, limiting the ability of combinational therapy with anabolic therapeutics to increase osteoblast bone formation $[134,135]$. We hypothesize that targeting $a 3$ will inhibit the osteoclastic resorptive activity without affecting the osteoclast numbers, thus not interfering with osteoclast-osteoblast cross talk and subsequent osteoblastic bone formation. V-ATPase $a$ subunits are not only attractive targets for osteolytic diseases, they are also considered therapeutic targets for the prevention of cancer, with increasing evidence that plasma membrane V-ATPases are required for extracellular acidification and subsequent metastasis [26]. 
V-ATPase are also therapeutic targets for fugal and viral infections; this is outside of the scope of this review, but was covered very well in a recent review [136]. V-ATPase-specific inhibitors such as bafilomycin and concanamycin induce apoptosis in all cell types. This highlights the fact that V-ATPase activity is essential for multiple cellular functions and the necessity to develop specific inhibitors targeting plasma membrane V-ATPases within osteoclasts and metastasizing cells. There are numerous studies looking at analogs of these plecomacrolides for derivatives with greater selectivity to osteoclast V-ATPases; this is, again, outside the scope of this review, but is well summarized in the recent review by Duan et al. [98]. Strategies for the targeting of $a 3$-containing V-ATPase can be grouped into three general categories: preventing cell-specific protein-protein interactions, targeting extracellular domains, and gene therapy.

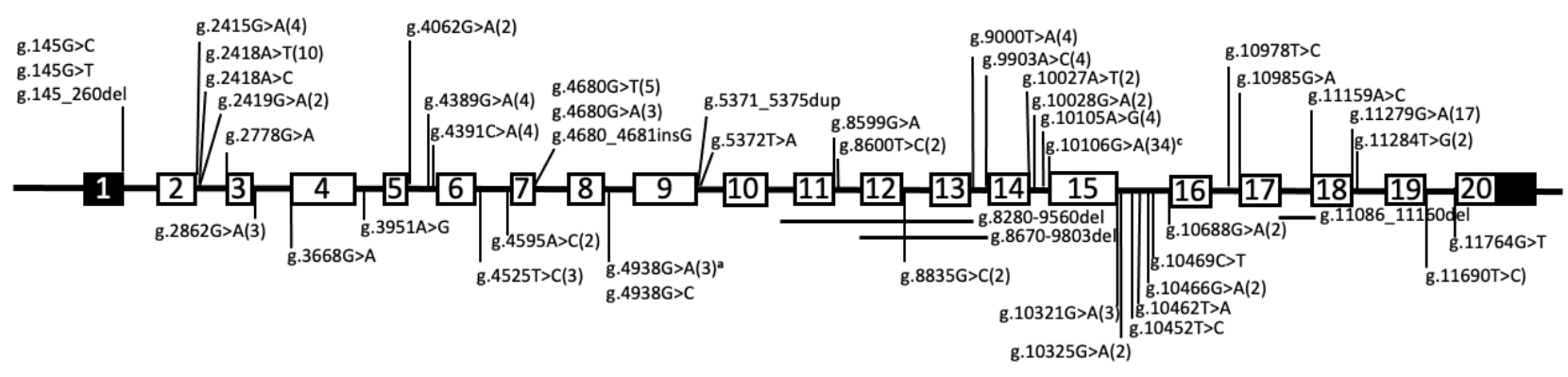

(a)

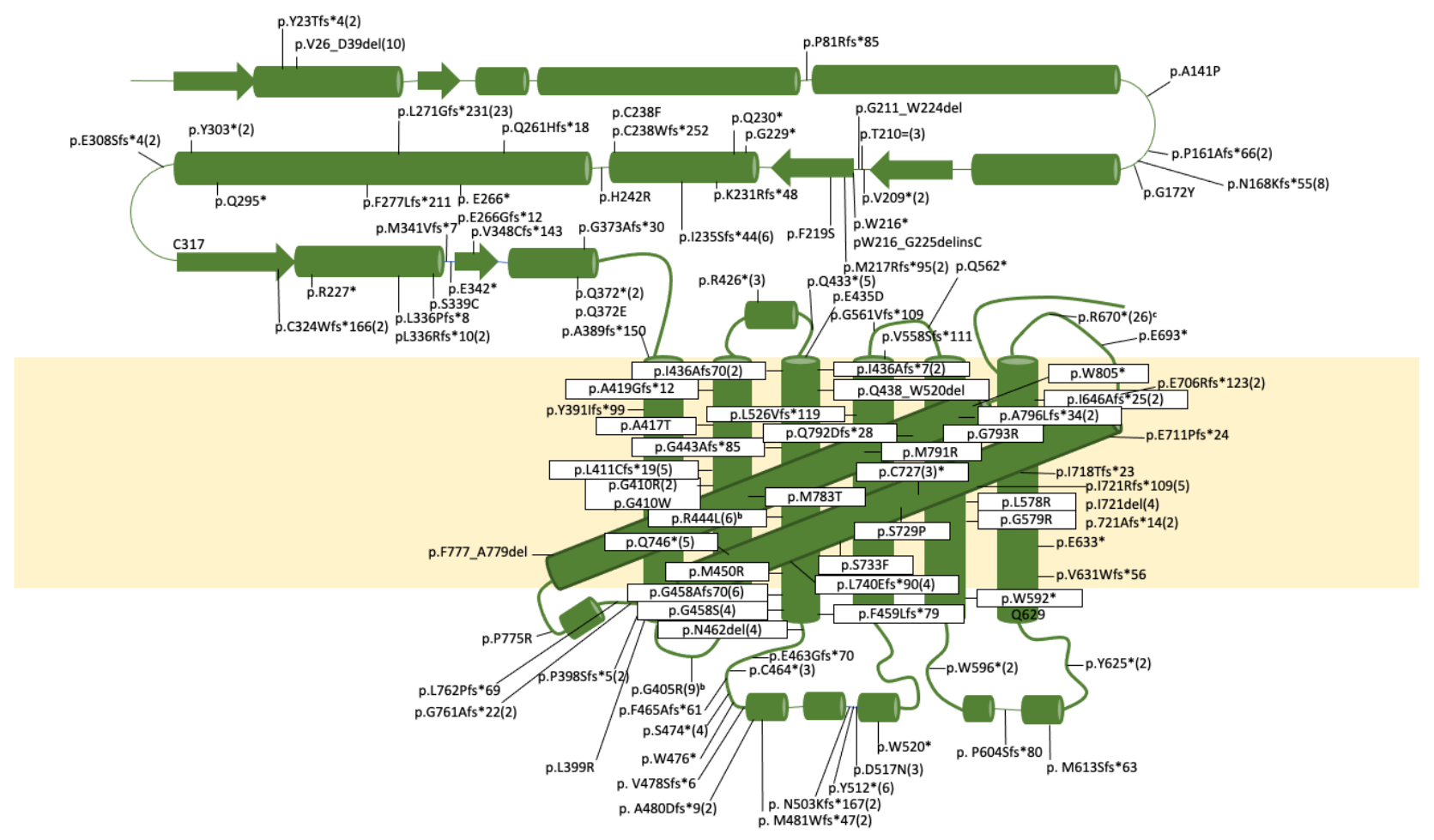

(b)

Figure 3. Mutations in TCIRG1 cause malignant autosomal recessive osteopetrosis (Table 2). (a) Splice-site mutations in the introns of TCIRG1. (b) Missense and small deletion mutations in the $a 3$ isoform. ${ }^{\text {a }}$ Founder effect in the Chuvashiya and Marians population; ${ }^{b}$ founder effect in the Costa Rica population; ${ }^{c}$ founder effect in the Flanders population.

Several groups, including our own, are working on targeting protein-protein interactions unique to V-ATPases on the plasma membrane of the osteoclast. Using the yeast two-hybrid assay, our group identified a direct protein-protein interaction between the $a 3$ and $d 2$ subunits, both of which are isoforms which are highly expressed in osteoclasts. 
We recreated this interaction in vitro with heterologously expressed proteins and used high-throughput screening to look for compounds that would inhibit the in vitro $d 2$ interaction with $a 3$, but not with the other $a 1, a 2$ and $a 4$ orthologs [102]. We were then able to show that one of these compounds, luteolin, reduced the osteoclastic resorption without affecting the osteoclast viability or actin ring formation [102]. Holliday's group found interactions between the V-ATPase $V_{1}$ B2 subunit and actin, and demonstrated that this interaction was essential for transporting V-ATPases to the osteoclast plasma membrane, which is essential to resorption. They computationally modeled this interaction in silica and performed a virtual screen for inhibitory compounds, resulting in the identification of enoxacin $[137,138]$. Holliday and others have subsequently shown that enoxacin and its derivative, bis-enoxacin, can prevent bone resorption in animal models $[139,140]$.

A second strategy is to generate inhibitory antibodies to epitopes located on the extracellular/luminal loops of subunit " $a$ ". This approach takes advantage of the fact that these domains should only be exposed to the extracellular surface when osteoclasts are actively resorbing bone, or when cancer cells are metastasizing and V-ATPases are localized on the plasma membrane. This approach is facilitated by the fact that the extracellular domains have been clearly defined both through biochemistry [141] and through structural analysis using cryo-electron microscopy [62]. A recent report showed that monoclonal antibodies against the V-ATPase $a 2$ subunit delayed ovarian tumor growth [142]. The inhibitory antibody was generated against amino acids $488-510$ in human $a 2$, which the authors stated is in the "transmembrane region of the protein" [143]. Nevertheless, the most recent structures of $a 1$ predict that residues $488-510$ of human $a 2$ would be in the large extracellular/luminal loop between transmembrane domains 3 and 4 [62]. Further, our group has shown that $a 2$ is glycosylated at residues N484 and N505 [82], providing biochemical evidence that this epitope is luminal/extracellular and thus accessible to anti- $a 2$ antibodies in culture media, supporting the overall strategy described above.

Finally, the use of gene therapy to decrease $a 3$ expression has been shown to be effective in decreasing both bone resorption and cell metastasis in cell culture and animal models. Hu et al. used small interfering RNA (siRNA) directed against $a 3$ and found reduced bone resorption in a rat osteoclast culture [144]. Jiang et al. locally injected an a3specific adeno-associated virus-mediated small-hairpin RNA (shRNA) into the periodontal tissues in vivo, and reported that it protected mice from P. gingivalis infection-stimulated bone resorption. In the same paper, they also reported that haploinsufficient Atp6i ${ }^{+/-}$mice were similarly protected from $P$. gingivalis infection-stimulated bone loss [145].

With respect to the prevention of metastasis, siRNAs and small-hairpin RNA (shRNA) specific to $a 3$ reduced the invasiveness of MCF10CA1a [146] and B16-F10 melanoma cells [147], respectively, while siRNA specific to both $a 3$ and $a 4$ inhibited the invasion of MB231 cells [148]. In contrast, Flinck et al. found that knocking down $a 3$ increased the migration and transwell invasion of pancreatic ductal adenocarcinoma cells, leading the authors to conclude that $a 3$ negatively regulates migration and invasion [149].

To summarize, the data from in vitro and in vivo models suggest that the reduction of a3 expression or $a 3$-specific interactions can prevent bone loss and cell metastasis. While encouraging, clinical trials with $a 3$ targeted therapeutics have yet to be reported.

\section{The Potential of the Correction of $a 3$ Splice Site and Missense Mutations to Treat Osteopetrosis}

As mentioned above and summarized in Figure 3, mutations in a 3 account for over $50 \%$ of infantile malignant autosomal recessive osteopetrosis. The majority of $a 3$ mutations predict no or severely truncated versions of $a 3$, leaving hematopoietic stem cell transplantation as the only current therapeutic option available. While effective, it must be performed during infancy for a successful outcome. Children diagnosed at an older age with milder forms of osteopetrosis currently have no treatment option, but the milder disease suggests the limited expression of functional a3. Our own study examined a 7 year old child with osteopetrosis resulting from a silent mutation in a conserved splice site motif [97]. The aberrant splicing reduced the full-length wildtype $a 3$ expression to approximately $5-10 \%$, 
explaining the phenotype but leaving the child without treatment options. Additional silent splice site mutations have been reported in older children with osteopetrosis [111]. While these children are not recommended for hematopoietic stem cell transplantation, the identification of aberrant splicing as the root cause suggests treatments focused on increasing the full length mRNA expression using specific small interfering RNAs [150] or splice-switching antisense oligonucleotides [151].

Similarly, the identification of specific missense mutations and understanding the precise molecular mechanisms underlying the mutation could help to inform a rational drug design. To this end, our group explored two human a3 mutations (G405R and R444L) by recreating them in the yeast ortholog, Vph1p (G424R and R462L) [115]. We found that both mutations did not affect the subunit expression, assembly or localization, but reduced hydrolytic rate and proton translocation, suggesting that these residues are critical to enzymatic activity and not amenable to rescue. In an alternate approach, our group used human embryonic kidney (HEK) transiently transfected with plasmids expressing $a 2$ and $a 4$ mutations identified in cases of cutis laxa and renal tubular acidosis, respectively. Two of the four mutations-a2 P405L and $a 4 \mathrm{R} 449 \mathrm{H}$ - affected protein stability and subsequent ER retention and degradation [30]. The identification of the folding/stability/ER exit issues as the primary molecular defect opens up the possibility of using chemical chaperones to stabilize the folding, thus escaping degradation and allowing ER exit.

\section{Future Directions}

Table 2 lists the splice site, missense and small deletion $a 3$ mutations resulting in osteopetrosis. As indicated in the table, the majority of these mutations were identified by genomic sequencing with no subsequent analysis, as access to patient tissue is understandably limited. Nevertheless, our group demonstrated different in vitro $[30,114,115]$ and in vivo approaches with limited patient tissue [97] to elucidate the molecular mechanism underlying the disease-causing mutations. Performing these analyses helps elucidate the $a 3$ residues critical to folding, ER exit, assembly, targeting and activity, and as detailed above, can open up therapeutic possibilities for osteopetrotic patients. The further identification of critical residues, regions and interactions unique to $a 3$ could also open up the possibility of screening for compounds to inhibit $a 3$ towards therapeutics for osteolytic diseases and cancer metastasis. Critical residues in predicted luminal/extracellular domains open up the possibility of inhibitory antibodies that could only access plasma membrane V-ATPase complexes. As we hope this review has highlighted, the analysis of $a 1, a 2$ and $a 4$ orthologs informs $a 3$ structure and function. As mentioned above, any therapeutic targeting of $a 3$ must be specific to plasma membrane $a 3$. To this end, it is critical that we understand where the targeting information resides, but this essential information is still not known. With respect to $a 3$ being a therapeutic target to prevent metastasis, similar to our approach targeting the osteoclast-specific $a 3-d 2$ interaction [102], the identification of cancer-specific subunit interactions could be informative. To this end, a recent paper did indeed look for cancer specific "V-ATPase molecular signatures" in a variety of different tumor cells [152]. Finally, as noted above, haploinsufficient Atp6i ${ }^{+/-}$mice were protected from bone loss in a bacterial infection-stimulated model of periodontal disease [145]. This result is at odds with the fact that both heterozygote mice and humans with only one wild type copy of $a 3$ are asymptomatic, but could reflect that in a disease/stressed state, the gene copy number becomes critical. Given the results of Jiang et al. [145], it would be of interest to note whether heterozygote $a 3 /$ - individuals are similarly protected against bone loss in inflammatory arthritis, periodontal disease and/or postmenopausal osteoporosis. 
Table 2. Summary of the described TCIRG1 mutations in osteopetrotic patients.

\begin{tabular}{|c|c|c|c|c|c|c|}
\hline \multicolumn{2}{|c|}{ Genomic $^{a}$} & \multirow{2}{*}{$\begin{array}{l}\text { cDNA }^{\mathbf{b}} \\
\text { Position }\end{array}$} & \multicolumn{2}{|c|}{ Protein $^{c}$} & \multirow{2}{*}{ Allele Freq. ${ }^{d}$} & \multirow{2}{*}{ Comment. [Ref] } \\
\hline Domain & Position & & Domain & Position & & \\
\hline Int1 & g.145G $>C$ & & & & 1 & [153] \\
\hline Int1 & g.145_260del & & & & 1 & [153] \\
\hline E2 & g.2363del & c.66del & PD & p.Y23Tfs*4 & 2 & Listed as c.65(E2):delC; p.22A>Afs5 [112,154] \\
\hline \multirow[t]{2}{*}{ Int2 } & g.2415G $>A$ & c. $117+1 \mathrm{G}>\mathrm{A}$ & & & 4 & [155-157] \\
\hline & g. $2418 \mathrm{~A}>\mathrm{T}$ & c. $117+4 \mathrm{~A}>\mathrm{T}$ & $\mathrm{PD}$ & p.V26_D39del & 10 & $\begin{array}{l}\text { Activates cryptic splice site in E2 resulting in a } \\
\text { deletion. }[96,156-159]\end{array}$ \\
\hline Int2 & g. $2418 \mathrm{~A}>\mathrm{C}$ & c. $117+4 \mathrm{~A}>\mathrm{C}$ & & & 1 & [108] \\
\hline Int2 & g.2419G $>A$ & c. $117+5 \mathrm{G}>\mathrm{A}$ & & & 2 & {$[154,156]$} \\
\hline Int2 & g.2778G $>A$ & $\mathrm{c} 118-1 \mathrm{G}>\mathrm{a}$ & & & 1 & [153] \\
\hline Int3 & g. $2862 \mathrm{G}>\mathrm{A}$ & c. $196+5 G>A$ & & & 3 & [154] \\
\hline Int3 & g.3668G $>A$ & c. $197-1 \mathrm{G}>\mathrm{A}$ & & & 1 & [153] \\
\hline Int 4 & g. $3951 \mathrm{~A}>\mathrm{G}$ & c. $418-21 \mathrm{~A}>\mathrm{G}$ & & & 1 & [154] \\
\hline E5 & g.3975G $>C$ & c. $421 \mathrm{G}>\mathrm{C}$ & DD & p.A141P & 1 & [156] \\
\hline E5 & & & DD & p.G159Rfs*68 & 1 & Listed with no details [161] \\
\hline E5 & g.4034dup & c.480dup & $\mathrm{DD}$ & p.P161Afs*66 & 2 & Listed as c.475dupC [153] \\
\hline Int5 & g. $4062 \mathrm{G}>\mathrm{A}$ & c. $503+5 \mathrm{G}>\mathrm{A}$ & & & 2 & [162] \\
\hline Int5 & g. $4389 \mathrm{G}>\mathrm{A}$ & c. $504-8 \mathrm{G}>\mathrm{A}$ & $\mathrm{DD}$ & $\begin{array}{l}\text { p.N168Kfs*55 and /or } \\
\text { p.N168Kfs*8 }\end{array}$ & 4 & $\begin{array}{l}\text { Activates cryptic splice in E6 resulting in a 11bp } \\
\text { deletion of E6 and/or skipping of E6 [156] }\end{array}$ \\
\hline Int5 & g. $4391 C>A$ & c. $504-6 C>A$ & $\mathrm{DD}$ & $\begin{array}{l}\text { p.N168Kfs*55 and /or } \\
\text { p.N168Kfs*8 }\end{array}$ & 4 & $\begin{array}{l}\text { Activates cryptic splice in E6 resulting in a 11bp } \\
\text { deletion of E6 and/or skipping of E6 }[53,158,163]\end{array}$ \\
\hline E6 & g.4406_4407delinsTA & c.514_515delinsTA & DD & p.G172Y & 1 & [164] \\
\hline
\end{tabular}


Table 2. Cont.

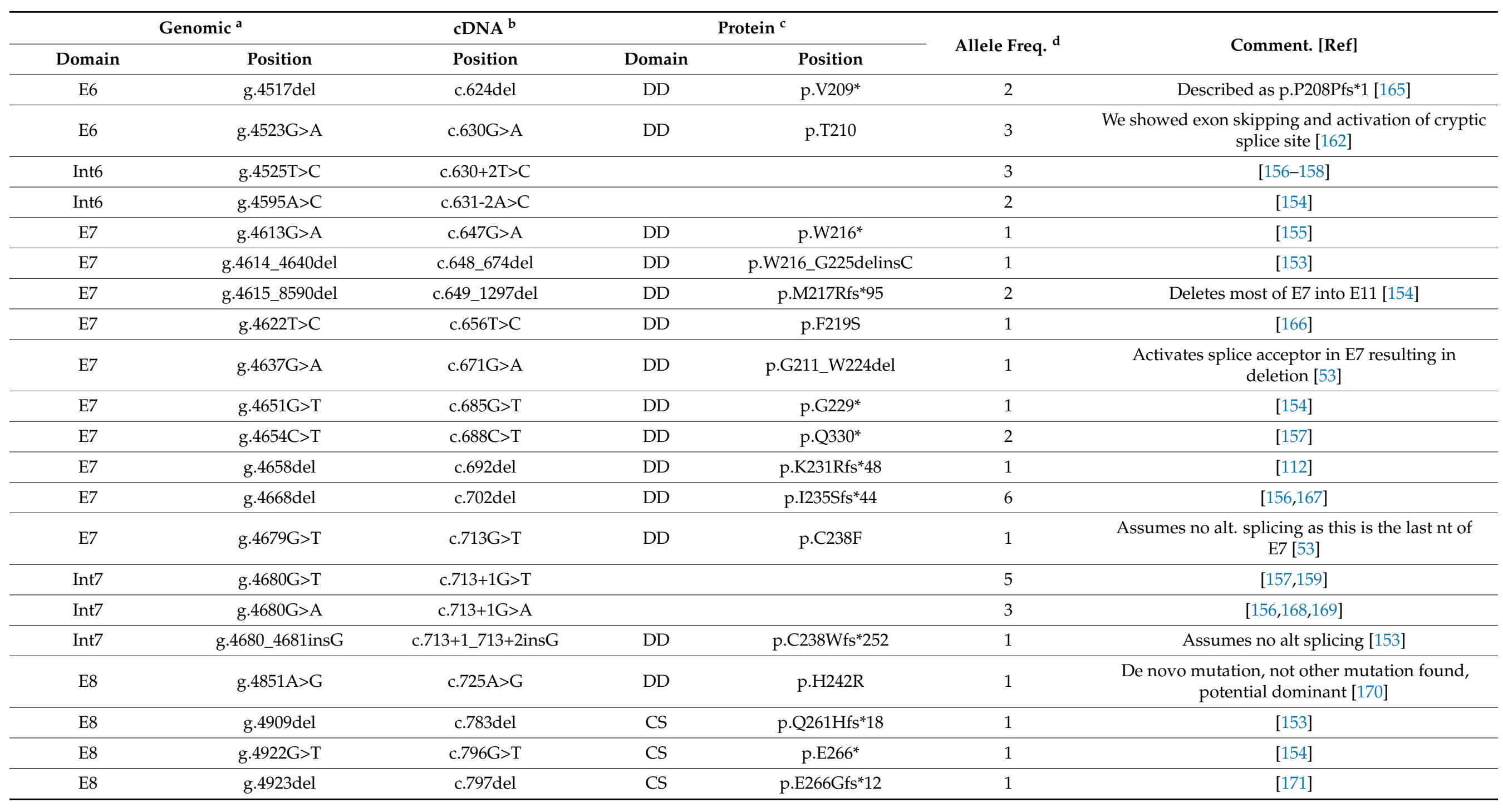


Table 2. Cont.

\begin{tabular}{|c|c|c|c|c|c|c|}
\hline \multicolumn{2}{|c|}{ Genomic $^{a}$} & \multirow{2}{*}{$\begin{array}{l}\text { cDNA }^{\text {b }} \\
\text { Position }\end{array}$} & \multicolumn{2}{|c|}{ Protein $^{c}$} & \multirow{2}{*}{ Allele Freq. ${ }^{d}$} & \multirow{2}{*}{ Comment. [Ref] } \\
\hline Domain & Position & & Domain & Position & & \\
\hline Int8 & g.4938G >A & c. $807+5 G>A$ & CS & p.L271Gfs*231 & 23 & $\begin{array}{l}\text { Founder mutation in Chuvashiya population. } \\
\text { Resulted in activation of cryptic splice donor 37nt } \\
\text { downstream. }[164,172]\end{array}$ \\
\hline Int8 & g.4938G $>C$ & c. $807+5 \mathrm{G}>\mathrm{T}$ & & & 1 & [153] \\
\hline E9 & g.5181_5186delinsA & c.831_836delinsA & CS & p.F277Lfs*211 & 1 & [173] \\
\hline E9 & g.5259C $>A$ & c. $909 \mathrm{C}>\mathrm{A}$ & $\mathrm{CS}$ & pY303* & 2 & {$[112,174]$} \\
\hline E9 & g.5272del & c.922del & CS & p.E308Sfs*4 & 2 & {$[53,156]$} \\
\hline E9 & g.5321_5322insG & c.971_972insG & PD & p.C324Wfs*166 & 2 & [157] \\
\hline E9 & g. $5329 \mathrm{C}>\mathrm{T}$ & c. $978 \mathrm{C}>\mathrm{T}$ & PD & pR327* & 1 & [153] \\
\hline E9 & g.5357del & c.1007del & PD & p.L336Rfs*10 & 2 & [155] \\
\hline E9 & g.5357_5363del & c.1007_1013del & PD & p.L336Pfs*8 & 2 & [154] \\
\hline E9 & g.5369_5370insGGTGA & c.1019_1020insGGTGA & PD & p.M341Vfs*7 & 1 & Described as p.340S>Sfs151 [154] \\
\hline Int9 & g.5371_5375dup & c.1020+1_1020+5dup & & & 1 & [165] \\
\hline Int9 & g.5372T>A & c. $1020+2 T>A$ & & & 1 & [153] \\
\hline E10 & g.5988G $>\mathrm{T}$ & c.1024G $>\mathrm{T}$ & PD & p.E342* & 1 & [96] \\
\hline E10 & g.6000_6001dupGTGC & c.1037_1040dup & PD & p.V348Cfs*143 & 1 & Described as c.1036_1037insGTGC [154] \\
\hline E10 & g.6078G > T & c. $1114 \mathrm{C}>\mathrm{T}$ & PD & p.Q372* & 2 & {$[154,160]$} \\
\hline E10 & g.6078C >G & & & & 1 & $\begin{array}{l}\text { listed as p.Q372* [157], but would be pQ372E if it is } \\
\text { g.6078C }>\mathrm{G}\end{array}$ \\
\hline \multirow[t]{2}{*}{ E10 } & g.6082del & c.1118del & PD & pG373Afs*30 & 1 & {$[153]$} \\
\hline & g.8280_9560del & c.1166_1554del & TM1 & p.A389Dfs*151 & 4 & Deletion includes E11-13 [156,158,168] \\
\hline E11 & g.8464_8465insA & c.1171_1174insA & TM1 & p.Y391Ifs*99 & 2 & Listed as g.8464insA $[153,157]$ \\
\hline
\end{tabular}


Table 2. Cont.

\begin{tabular}{|c|c|c|c|c|c|c|}
\hline \multicolumn{2}{|c|}{ Genomic $^{a}$} & \multirow{2}{*}{$\begin{array}{l}\text { cDNA }^{b} \\
\text { Position }\end{array}$} & \multicolumn{2}{|c|}{ Protein $^{c}$} & \multirow{2}{*}{ Allele Freq. ${ }^{d}$} & \multirow{2}{*}{ Comment. [Ref] } \\
\hline Domain & Position & & Domain & Position & & \\
\hline E11 & g.8484del & c.1191del & TM1 & p.F398Sfs*5 & 2 & Listed as c.1188delC; p.P397Pfs6 [154] \\
\hline E11 & g. $8506 \mathrm{G}>\mathrm{A}$ & c. $1213 \mathrm{G}>\mathrm{A}$ & TM1 & p.G405R & 23 & $\begin{array}{c}\text { Founder mutation effect in Costa Rica } \\
{[112,153,154,156,157,162,168]}\end{array}$ \\
\hline E11 & g. $8521 \mathrm{G}>\mathrm{A}$ & c. $1228 \mathrm{G}>\mathrm{A}$ & TM2 & p.G410R & 1 & [168] \\
\hline E11 & g. $8521 G>C$ & c. $1228 \mathrm{G}>\mathrm{C}$ & TM2 & p.G410R & 1 & [153] \\
\hline E11 & g.8523del & c.1230del & TM2 & p.L411Cfs*19 & 5 & $\begin{array}{c}\text { Listed as Pt1 delG8521; p>G410fsX429 or Pt20 } \\
\text { g.8521delG }[158,168,169]\end{array}$ \\
\hline E11 & g. $8542 \mathrm{G}>\mathrm{A}$ & c. $1249 \mathrm{G}>\mathrm{A}$ & TM2 & p.A417T & 1 & [153] \\
\hline E11 & g.8548_8549insGG & c.1255_1256insGG & TM2 & p.A419Gfs*12 & 1 & [153] \\
\hline E11 & g. $8569 \mathrm{C}>\mathrm{T}$ & c. $1276 \mathrm{C}>\mathrm{t}$ & CL1 & p.R426* & 3 & {$[153,175]$} \\
\hline E11 & g. $8598 \mathrm{G}>\mathrm{C}$ & c. $1305 \mathrm{G}>\mathrm{T}$ & TM3 & p.E435D & 1 & [153] \\
\hline Int11 & g. $8599 \mathrm{G}>\mathrm{A}$ & c. $1305+1 G>A$ & & & 1 & [153] \\
\hline \multirow[t]{2}{*}{ Int11 } & g. $8600 \mathrm{~T}>\mathrm{C}$ & c. $1305+2 \mathrm{~T}>\mathrm{C}$ & & & 2 & {$[110,159]$} \\
\hline & g.8670_9803del & c.1306_1554del & TM3 & p.Q438_W520del & 1 & $\begin{array}{l}\text { Deletion includes E12-13. Checked both DNA anc } \\
\text { cDNA [153] }\end{array}$ \\
\hline E12 & g.8695del & c.1328del & TM3 & p.G443Afs*85 & 1 & [153] \\
\hline E12 & g. $8698 \mathrm{G}>\mathrm{T}$ & c. $1331 G>T$ & TM3 & p.R444L & 6 & Founder effect in Cost Rica population [157] \\
\hline E12 & g. $8716 \mathrm{~T}>\mathrm{G}$ & c.1349T>G & TM3 & p.M450R & 1 & [153] \\
\hline E12 & g.8738del & c.1371del & TM3 & p.G458Afs*70 & 6 & Listed as c.1370delc; p.T457Tfs71 [154] \\
\hline E12 & g. $8738 \mathrm{C}>\mathrm{A}$ & c. $1371 \mathrm{C}>\mathrm{A}$ & TM3 & p.I436Afs*70 & 2 & $\begin{array}{l}\text { Creates cryptic splice acceptor, results in the } \\
\text { deletion of } 67 \mathrm{nt} \text { of E12 [176] }\end{array}$ \\
\hline
\end{tabular}


Table 2. Cont.

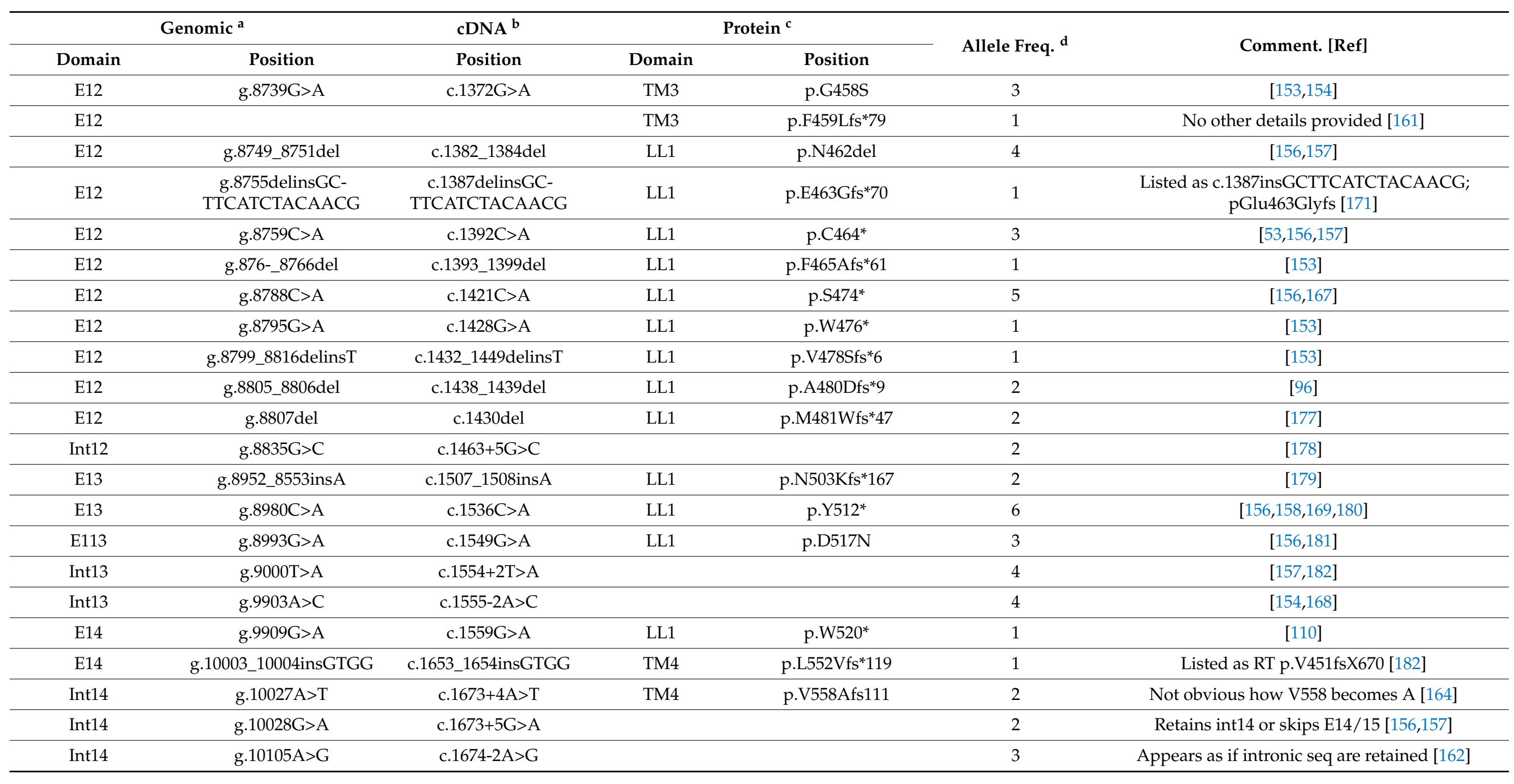


Table 2. Cont.

\begin{tabular}{|c|c|c|c|c|c|c|}
\hline \multicolumn{2}{|c|}{ Genomic $^{a}$} & \multirow{2}{*}{$\begin{array}{l}\text { cDNA }^{b} \\
\text { Position }\end{array}$} & \multicolumn{2}{|c|}{ Protein $^{c}$} & \multirow{2}{*}{ Allele Freq. ${ }^{d}$} & \multirow{2}{*}{ Comment. [Ref] } \\
\hline Domain & Position & & Domain & Position & & \\
\hline Int14 & g.10106G >A & c. $1674-1 \mathrm{G}>\mathrm{A}$ & & & 34 & $\begin{array}{l}\text { Founder mutation if Flanders population } \\
\qquad[53,156,157,159,168,169]\end{array}$ \\
\hline E15 & g.10115delinsTT & c.1682delinsTT & LL2 & p.G561Vfs*109 & 1 & [168] \\
\hline E15 & g.10117C > T & c. $1684 \mathrm{C}>\mathrm{T}$ & LL2 & p.Q562* & 1 & [182] \\
\hline E15 & g.10166T>G & c. $1733 \mathrm{~T}>\mathrm{G}$ & TM5 & p.L578R & 1 & [154] \\
\hline E15 & g.10208G >A & c. $1775 \mathrm{G}>\mathrm{A}$ & TM5 & p.W592* & 1 & [154] \\
\hline E15 & g.10220G >A & c. $1787 \mathrm{G}>\mathrm{A}$ & LL2 & p.W596* & 2 & [96] \\
\hline E15 & g.10242_10251del & c.1809_1818del & LL2 & p.P604Sfs*80 & 1 & [163] \\
\hline E15 & g.10270_10273del & c.1837_1840del & LL2 & p.M613Sfs*63 & 1 & [154] \\
\hline E15 & g.10311C>A & c. $1878 \mathrm{C}>\mathrm{A}$ & LL2 & p.Y625* & 2 & [168] \\
\hline Int15 & g.10321G>A & c. $1887+1 G>A$ & & & 3 & [154] \\
\hline Int15 & g. $10452 \mathrm{~T}>\mathrm{C}$ & c. $1887+132 \mathrm{~T}>\mathrm{C}$ & & & 1 & [110] \\
\hline Int15 & g.10462T>A & c. $1887+142 \mathrm{~T}>\mathrm{A}$ & & & 1 & retains $6.7 \%$ wt splicing [110] \\
\hline Int15 & g.10466G>A & c. $1887+146 \mathrm{G}>\mathrm{A}$ & & & 2 & retains 5.5\% wt splicing [110] \\
\hline Int15 & g. $10469 \mathrm{C}>\mathrm{T}$ & c. $1887+149 \mathrm{C}>\mathrm{T}$ & & & 1 & [110] \\
\hline Int15 & g.10688G>A & c. $1888-1 G>A$ & & & 2 & Listed asc.1874-1G>A [168] \\
\hline E16 & g.10692del & c.1891del & TM6 & p.V631Wfs*56 & 1 & Listed as c.1878delG [153] \\
\hline E16 & g.10698C >T & c. $1897 \mathrm{C}>\mathrm{T}$ & TM6 & p.E633* & 1 & [154] \\
\hline E16 & g.10735_10736insGGCA & c.1934_1935insGGCA & TM6 & p.I646Afs*25 & 2 & [166] \\
\hline E16 & g. $10809 \mathrm{C}>\mathrm{T}$ & c. $2008 \mathrm{C}>\mathrm{T}$ & CL3 & p.Arg670* & 26 & $\begin{array}{l}\text { Founder variant in Flander population } \\
\qquad[154,156,157,168,174]\end{array}$ \\
\hline
\end{tabular}


Table 2. Cont.

\begin{tabular}{|c|c|c|c|c|c|c|}
\hline \multicolumn{2}{|c|}{ Genomic $^{a}$} & \multirow{2}{*}{$\begin{array}{l}\text { cDNA }^{b} \\
\text { Position }\end{array}$} & \multicolumn{2}{|c|}{ Protein ${ }^{c}$} & \multirow{2}{*}{ Allele Freq. ${ }^{d}$} & \multirow{2}{*}{ Comment. [Ref] } \\
\hline Domain & Position & & Domain & Position & & \\
\hline Int16 & g.10978T>C & c.2014-8T>C & & & & [157] \\
\hline E17 & g.11049G>T & c. $2077 \mathrm{G}>\mathrm{T}$ & CL3 & p.E693* & 1 & [153] \\
\hline E17 & g.11086_11160del & c.2114_2119-1del & CL3 & p.E706Rfs*123 & 2 & Deletes last 5nt of E17 and all if Int17 [157] \\
\hline Int17 & g.11159A >C & c. $2119-2 \mathrm{~A}>\mathrm{C}$ & & & 1 & [153] \\
\hline E18 & g.11172_11190del & c.2130_2148del & TM7 & p.E711Pfs*24 & 1 & [153] \\
\hline E18 & g.11195del & c.2153del & TM7 & p.I718Tfs*23 & 1 & [156] \\
\hline E18 & g.11202_11204del & c.2160_2162del & TM7 & p.I721Rfs*109 & 5 & [182] \\
\hline E18 & g.11203_11205del & c.2161_2163del & TM7 & p.I721del & 4 & {$[154,156,166]$} \\
\hline E18 & & & TM7 & pI721Afs*14 & 2 & No data shown [161] \\
\hline E18 & g. $11223 \mathrm{C}>\mathrm{A}$ & c. $2181 \mathrm{C}>\mathrm{A}$ & TM7 & p.C727* & 3 & {$[112,154]$} \\
\hline E18 & g.11227T>C & c. $2185 \mathrm{C}>\mathrm{T}$ & TM7 & p.S729P & 1 & [153] \\
\hline E18 & g.11260_11261del & c.2218_2219del & TM7 & p.L740Qfs*90 & 4 & {$[154,168]$} \\
\hline E18 & g. $11278 \mathrm{C}>\mathrm{T}$ & c. $2236 \mathrm{C}>\mathrm{T}$ & TM7 & p.Q746* & 5 & Assumes splicing to E19 $[159,169,181,183]$. \\
\hline Int18 & g.11279G >A & c. $2236+1 G>A$ & & & 17 & $\begin{array}{c}\text { PCR analysis shows minor wt transcript, and at } \\
\text { least } 5 \text { alternative splice events } \\
{[156-158,162,168,169]}\end{array}$ \\
\hline E19 & g.11556del & c.2282del & & p.G761Afs*22 & 2 & [153] \\
\hline E19 & g.11558_11559insC & c.2284_2285insC & & p.L762Pfs*69 & 1 & [153] \\
\hline E19 & g.11598C>G & c. $2324 \mathrm{C}>\mathrm{G}$ & TM8 & p.P775R & 6 & {$[156,157,168]$} \\
\hline E19 & g.11602_11610del & c.2328_2336del & TM8 & p.F777_A779del & 1 & [157] \\
\hline E19 & g. $11622 \mathrm{~T}>\mathrm{C}$ & c. $2348 \mathrm{~T}>\mathrm{C}$ & TM8 & pM783T & 2 & {$[110,158]$} \\
\hline E19 & g.11646T>G & c. $2372 \mathrm{~T}>\mathrm{G}$ & TM8 & p.M791R & 1 & [153] \\
\hline
\end{tabular}


Table 2. Cont.

\begin{tabular}{|c|c|c|c|c|c|c|}
\hline \multicolumn{2}{|c|}{ Genomic $^{a}$} & \multirow{2}{*}{$\begin{array}{l}\text { cDNA }^{\mathbf{b}} \\
\text { Position }\end{array}$} & \multicolumn{2}{|c|}{ Protein ${ }^{c}$} & \multirow{2}{*}{ Allele Freq. ${ }^{d}$} & \multirow{2}{*}{ Comment. [Ref] } \\
\hline Domain & Position & & Domain & Position & & \\
\hline E19 & g.11647_11650del & c.2376_2379del & TM8 & p.Q792Dfs*28 & 2 & {$[157,158]$} \\
\hline E19 & g.11654_11655del & c.2380_2381del & TM8 & p.A796Lfs*34 & 1 & [108] \\
\hline E19 & g.11657_11658del & c.2383_2384del & TM8 & p.A796Lfs*34 & 1 & [168] \\
\hline Int19 & g.11690T>C & c. $2414+2 \mathrm{~T}>\mathrm{C}$ & & & 1 & [173] \\
\hline Int19 & g. $11764 \mathrm{G}>\mathrm{T}$ & c. $2115-1 G>T$ & & & 1 & [155] \\
\hline E20 & g.11765G>A & c. $2415 \mathrm{G}>\mathrm{A}$ & TM8 & p.W805* & 1 & Assumes correct splicing. This is 1st nt in E20 [96]. \\
\hline
\end{tabular}

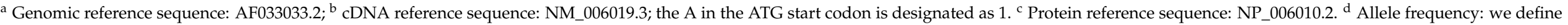

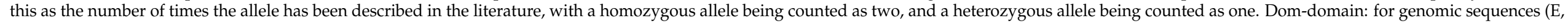

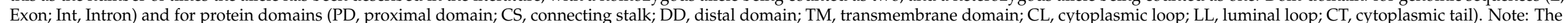

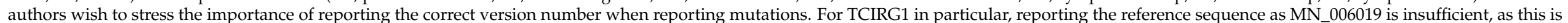

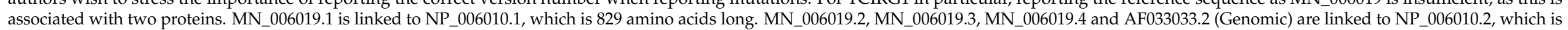

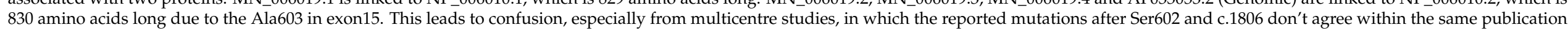
because different reference sequence versions were used by the labs. Our table has been adjusted to reflect this difference. 
Author Contributions: All authors contributed to the writing of this manuscript. All authors have read and agreed to the published version of the manuscript.

Funding: This work was supported by the Canadian Institutes of Health Research Grant\# PJT-148508 (to M.F.M.)

Institutional Review Board Statement: Not applicable.

Informed Consent Statement: Not applicable.

Data Availability Statement: Not applicable.

Acknowledgments: M.F.M. would like to acknowledge and thank Yeqi Yao for her 21 years of dedication to our lab, and wish her the best in her well-deserved retirement.

Conflicts of Interest: The authors declare no conflict of interest.

\section{References}

1. Lin, X.; Patil, S.; Gao, Y.-G.; Qian, A. The Bone Extracellular Matrix in Bone Formation and Regeneration. Front. Pharmacol. 2020, 11, 757. [CrossRef] [PubMed]

2. Lee, D.; Kim, D.W.; Cho, J.-Y. Correction to: Role of growth factors in hematopoietic stem cell niche. Cell Biol. Toxicol. $2020,36,1$. [CrossRef]

3. Kitaura, H.; Marahleh, A.; Ohori, F.; Noguchi, T.; Shen, W.-R.; Qi, J.; Nara, Y.; Pramusita, A.; Kinjo, R.; Mizoguchi, I. OsteocyteRelated Cytokines Regulate Osteoclast Formation and Bone Resorption. Int. J. Mol. Sci. 2020, 21, 5169. [CrossRef] [PubMed]

4. Roeder, E.; Matthews, B.G.; Kalajzic, I. Visual reporters for study of the osteoblast lineage. Bone 2016, 92, 189-195. [CrossRef]

5. Prideaux, M.; Findlay, D.M.; Atkins, G.J. Osteocytes: The master cells in bone remodelling. Curr. Opin. Pharmacol. 2016, 28, 24-30. [CrossRef]

6. Creecy, A.; Damrath, J.G.; Wallace, J.M. Control of Bone Matrix Properties by Osteocytes. Front. Endocrinol. 2021, 11, 578477. [CrossRef] [PubMed]

7. Chen, X.; Wang, Z.; Duan, N.; Zhu, G.; Schwarz, E.M.; Xie, C. Osteoblast-osteoclast interactions. Connect. Tissue Res. 2018, 59, 99-107. [CrossRef] [PubMed]

8. Jacome-Galarza, C.E.; Percin, G.I.; Muller, J.T.; Mass, E.; Lazarov, T.; Eitler, J.; Rauner, M.; Yadav, V.K.; Crozet, L.; Bohm, M.; et al. Developmental origin, functional maintenance and genetic rescue of osteoclasts. Nat. Cell Biol. 2019, 568, 541-545. [CrossRef]

9. Yahara, Y.; Barrientos, T.; Tang, Y.J.; Puviindran, V.; Nadesan, P.; Zhang, H.; Gibson, J.R.; Gregory, S.G.; Diao, Y.; Xiang, Y.; et al. Erythromyeloid progenitors give rise to a population of osteoclasts that contribute to bone homeostasis and repair. Nat. Cell Biol. 2020, 22, 49-59. [CrossRef]

10. Søe, K.; Delaisse, J.-M.; Borggaard, X.G. Osteoclast formation at the bone marrow /bone surface interface: Importance of structural elements, matrix, and intercellular communication. Semin. Cell Dev. Biol. 2020, 112, 8-15. [CrossRef]

11. Sims, N.A.; Martin, T.J. Osteoclasts Provide Coupling Signals to Osteoblast Lineage Cells Through Multiple Mechanisms. Annu. Rev. Physiol. 2020, 82, 507-529. [CrossRef] [PubMed]

12. Takito, J.; Nakamura, M. Heterogeneity and Actin Cytoskeleton in Osteoclast and Macrophage Multinucleation. Int. J. Mol. Sci. 2020, 21, 6629. [CrossRef] [PubMed]

13. Gambari, L.; Grassi, F.; Roseti, L.; Grigolo, B.; Desando, G. Learning from Monocyte-Macrophage Fusion and Multinucleation: Potential Therapeutic Targets for Osteoporosis and Rheumatoid Arthritis. Int. J. Mol. Sci. 2020, 21, 6001. [CrossRef] [PubMed]

14. Takito, J.; Inoue, S.; Nakamura, M. The Sealing Zone in Osteoclasts: A Self-Organized Structure on the Bone. Int. J. Mol. Sci. 2018, 19, 984. [CrossRef] [PubMed]

15. Mulari, M.T.K.; Zhao, H.; Lakkakorpi, P.T.; Väänänen, H.K. Osteoclast Ruffled Border Has Distinct Subdomains for Secretion and Degraded Matrix Uptake. Traffic 2003, 4, 113-125. [CrossRef] [PubMed]

16. Toyomura, T.; Murata, Y.; Yamamoto, A.; Oka, T.; Sun-Wada, G.H.; Wada, Y.; Futai, M. From lysosomes to the plasma membrane: Localization of vacuolar-type H+ -ATPase with the a3 isoform during osteoclast differentiation. J. Biol. Chem. 2003, 278, 22023-22030. [CrossRef]

17. Ng, P.Y.; Ribet, A.B.P.; Pavlos, N.J. Membrane trafficking in osteoclasts and implications for osteoporosis. Biochem. Soc. Trans. 2019, 47, 639-650. [CrossRef]

18. Kim, J.H.; Kim, N. Bone Cell Communication Factors Provide a New Therapeutic Strategy for Osteoporosis. Chonnam. Med. J. 2020, 56, 94-98. [CrossRef]

19. Wang, H.; Yang, G.; Xiao, Y.; Luo, G.; Li, G.; Li, Z. Friend or Foe? Essential Roles of Osteoclast in Maintaining Skeletal Health. BioMed Res. Int. 2020, 2020, 1-10. [CrossRef]

20. Corbacho, I.; Teixidó, F.; Olivero, I.; Hernández, L.M. Dependence of Saccharomyces cerevisiae Golgi functions on V-ATPase activity. FEMS Yeast Res. 2012, 12, 341-350. [CrossRef]

21. Nelson, N. Structure and function of V-ATPases in endocytic and secretory organelles. J. Exp. Biol. 1992, 172, 149-153. [CrossRef]

22. Perzov, N.; Padler-Karavani, V.; Nelson, H.; Nelson, N. Characterization of yeast V-ATPase mutants lacking Vph1p or Stv1p and the effect on endocytosis. J. Exp. Biol. 2002, 205, 1209-1219. [CrossRef] [PubMed] 
23. Márquez-Sterling, N.; Herman, I.M.; Pesacreta, T.; Arai, H.; Terres, G.; Forgac, M. Immunolocalization of the vacuolar-type (H+)-ATPase from clathrin-coated vesicles. Eur. J. Cell Biol. 1991, 56, 19-33.

24. Kissing, S.; Hermsen, C.; Repnik, U.; Nesset, C.K.; von Bargen, K.; Griffiths, G.; Ichihara, A.; Lee, B.S.; Schwake, M.; De Brabander, J.; et al. Vacuolar ATPase in Phagosome-Lysosome Fusion. J. Biol. Chem. 2015, 290, 14166-14180. [CrossRef] [PubMed]

25. Sun-Wada, G.-H.; Wada, Y. Role of vacuolar-type proton ATPase in signal transduction. Biochim. et Biophys. Acta (BBA) Bioenerg. 2015, 1847, 1166-1172. [CrossRef]

26. Stransky, L.; Cotter, K.; Forgac, M. The Function of V-ATPases in Cancer. Physiol. Rev. 2016, 96, 1071-1091. [CrossRef] [PubMed]

27. Kibak, H.; Taiz, L.; Starke, T.; Bernasconi, P.; Gogarten, J.P. Evolution of structure and function of V-ATPases. J. Bioenerg. Biomembr. 1992, 24, 415-424. [CrossRef]

28. Sun-Wada, G.-H.; Wada, Y.; Futai, M. Vacuolar H+ pumping ATPases in luminal acidic organelles and extracellular compartments: Common rotational mechanism and diverse physiological roles. J. Bioenerg. Biomembr. 2003, 35, 347-358. [CrossRef]

29. Futai, M.; Oka, T.; Sun-Wada, G.; Moriyama, Y.; Kanazawa, H.; Wada, Y. Luminal acidification of diverse organelles by V-ATPase in animal cells. J. Exp. Biol. 2000, 203, 107-116. [CrossRef]

30. Esmail, S.; Kartner, N.; Yao, Y.; Kim, J.W.; Reithmeier, R.A.; Manolson, M.F. Molecular mechanisms of cutis laxa- and distal renal tubular acidosis-causing mutations in V-ATPase a subunits, ATP6V0A2 and ATP6V0A4. J. Biol. Chem. 2018, 293, 2787-2800. [CrossRef]

31. Mindell, J.A. Lysosomal Acidification Mechanisms. Annu. Rev. Physiol. 2012, 74, 69-86. [CrossRef] [PubMed]

32. Futai, M.; Sun-Wada, G.H.; Wada, Y.; Matsumoto, N.; Nakanishi-Matsui, M. Vacuolar-type ATPase: A proton pump to lysosomal trafficking. Proc. Jpn. Acad. Ser. B Phys. Biol. Sci. 2019, 95, 17. [CrossRef] [PubMed]

33. Lu, X.; Meima, M.E.; Nelson, J.K.; Sorrentino, V.; Loregger, A.; Scheij, S.; Dekkers, D.H.; Mulder, M.T.; Demmers, J.A.; M-DallingaThie, G.; et al. Identification of the (Pro)renin Receptor as a Novel Regulator of Low-Density Lipoprotein MetabolismNovelty and Significance. Circ. Res. 2016, 118, 222-229. [CrossRef] [PubMed]

34. Yeganeh, B.; Ghavami, S.; Kroeker, A.L.; Mahood, T.H.; Stelmack, G.L.; Klonisch, T.; Coombs, K.; Halayko, A.J. Suppression of influenza A virus replication in human lung epithelial cells by noncytotoxic concentrations bafilomycin A1. Am. J. Physiol. Cell. Mol. Physiol. 2015, 308, L270-L286. [CrossRef] [PubMed]

35. Müller, K.H.; E Kainov, D.; El Bakkouri, K.; Saelens, X.; De Brabander, J.K.; Kittel, C.; Samm, E.; Muller, C.P. The proton translocation domain of cellular vacuolar ATPase provides a target for the treatment of influenza A virus infections. Br. J. Pharmacol. 2011, 164, 344-357. [CrossRef] [PubMed]

36. Gary-Bobo, M.; Nirdé, P.; Jeanjean, A.; Morère, A.; Garcia, M. Mannose 6-Phosphate Receptor Targeting and its Applications in Human Diseases. Curr. Med. Chem. 2007, 14, 2945-2953. [CrossRef]

37. Abu-Remaileh, M.; Wyant, G.A.; Kim, C.; Laqtom, N.N.; Abbasi, M.; Chan, S.H.; Freinkman, E.; Sabatini, D.M. Lysosomal metabolomics reveals V-ATPase- and mTOR-dependent regulation of amino acid efflux from lysosomes. Science 2017, 358 , 807-813. [CrossRef]

38. Efeyan, A.; Zoncu, R.; Sabatini, D.M. Amino acids and mTORC1: From lysosomes to disease. Trends Mol. Med. 2012, 18, 524-533. [CrossRef]

39. Zoncu, R.; Bar-Peled, L.; Efeyan, A.; Wang, S.; Sancak, Y.; Sabatini, D.M. mTORC1 Senses Lysosomal Amino Acids Through an Inside-Out Mechanism That Requires the Vacuolar H+-ATPase. Science 2011, 334, 678-683. [CrossRef]

40. Stransky, L.A.; Forgac, M. Amino Acid Availability Modulates Vacuolar H+-ATPase Assembly. J. Biol. Chem. 2015, 290, 27360-27369. [CrossRef]

41. Rama, S.; Boumedine-Guignon, N.; Sangiardi, M.; Youssouf, F.; Maulet, Y.; Lévêque, C.; Belghazi, M.; Seagar, M.; Debanne, D.; El Far, O. Chromophore-Assisted Light Inactivation of the V-ATPase V0c Subunit Inhibits Neurotransmitter Release Downstream of Synaptic Vesicle Acidification. Mol. Neurobiol. 2018, 56, 3591-3602. [CrossRef]

42. Morel, N.; Poëa-Guyon, S. The membrane domain of vacuolar H+ATPase: A crucial player in neurotransmitter exocytotic release. Cell. Mol. Life Sci. 2015, 72, 2561-2573. [CrossRef] [PubMed]

43. Morel, N. Neurotransmitter release: The dark side of the vacuolar-H+ATPase. Biol. Cell 2003, 95, 453-457. [CrossRef]

44. Marshansky, V.R.; Grüber, G. Eukaryotic V-ATPase: Novel structural findings and functional insights. Biochim. Biophys. Acta 2014, 1837, 23. [CrossRef]

45. Sun-Wada, G.H.; Toyomura, T.; Murata, Y.; Yamamoto, A.; Futai, M.; Wada, Y. The a3 isoform of V-ATPase regulates insulin secretion from pancreatic beta-cells. J. Cell. Sci. 2006, 119, 4531-4540. [CrossRef] [PubMed]

46. Sun-Wada, G.-H.; Tabata, H.; Kawamura, N. Selective Assembly of V-ATPase Subunit Isoforms in Mouse Kidney. J. Bioenerg. Biomembr. 2005, 37, 415-418. [CrossRef] [PubMed]

47. Brown, D.; Sabolic, I.; Gluck, S. Polarized targeting of V-ATPase in kidney epithelial cells. J. Exp. Biol. 1992, 172, 231-243. [CrossRef]

48. Hermo, L.; I Adamali, H.; Andonian, S. Immunolocalization of CA II and H+ V-ATPase in epithelial cells of the mouse and rat epididymis. J. Androl. 2000, 21, 376-391.

49. Pietrement, C.; Sun-Wada, G.-H.; Da Silva, N.; McKee, M.; Marshansky, V.; Brown, D.; Futai, M.; Breton, S. Distinct Expression Patterns of Different Subunit Isoforms of the V-ATPase in the Rat Epididymis1. Biol. Reprod. 2006, 74, 185-194. [CrossRef] [PubMed] 
50. Qin, A.; Cheng, T.; Pavlos, N.; Lin, Z.; Dai, K.; Zheng, M. V-ATPases in osteoclasts: Structure, function and potential inhibitors of bone resorption. Int. J. Biochem. Cell Biol. 2012, 44, 1422-1435. [CrossRef]

51. Kartner, N.; Manolson, M. V-ATPase subunit interactions: The long road to therapeutic targeting. Curr. Protein Pept. Sci. 2012, 13, 164-179. [CrossRef]

52. Hinton, A.; Bond, S.; Forgac, M. V-ATPase functions in normal and disease processes. Pflügers Arch. Eur. J. Physiol. 2009, 457, 589-598. [CrossRef]

53. Frattini, A.; Orchard, P.J.; Sobacchi, C.; Giliani, S.; Abinun, M.; Mattsson, J.P.; Keeling, D.J.; Andersson, A.-K.; Wallbrandt, P.; Zecca, L.; et al. Defects in TCIRG1 subunit of the vacuolar proton pump are responsible for a subset of human autosomal recessive osteopetrosis. Nat. Genet. 2000, 25, 343-346. [CrossRef]

54. Nakhoul, N.L.; Hamm, L.L. Vacuolar H(+)-ATPase in the kidney. J. Nephrol. 2002, 15, 22-31.

55. Kartner, N.; Yao, Y.; Li, K.; Crasto, G.J.; Datti, A.; Manolson, M.F. Inhibition of Osteoclast Bone Resorption by Disrupting Vacuolar H+-ATPase a3-B2 Subunit Interaction. J. Biol. Chem. 2010, 285, 37476-37490. [CrossRef]

56. Blair, H.C.; Teitelbaum, S.L.; Ghiselli, R.; Gluck, S. Osteoclastic bone resorption by a polarized vacuolar proton pump. Science 1989, 245, 855-857. [CrossRef] [PubMed]

57. Collins, M.P.; Forgac, M. Regulation of V-ATPase Assembly in Nutrient Sensing and Function of V-ATPases in Breast Cancer Metastasis. Front. Physiol. 2018, 9, 902. [CrossRef] [PubMed]

58. Michel, V.; Munoz, Y.L.; Trujillo, K.; Bisoffi, M.; Parra, K.J. Inhibitors of vacuolar ATPase proton pumps inhibit human prostate cancer cell invasion and prostate-specific antigen expression and secretion. Int. J. Cancer 2013, 132, E1-E10. [CrossRef] [PubMed]

59. Jung, Y.S.; Jun, S.; Kim, M.J.; Lee, S.H.; Suh, H.N.; Lien, E.M.; Jung, H.Y.; Lee, S.; Zhang, J.; Yang, J.I.; et al. TMEM9 promotes intestinal tumorigenesis through vacuolar-ATPase-activated Wnt/beta-catenin signalling. Nat. Cell Biol. 2018, 20, 1421-1433. [CrossRef]

60. Wang, D.; Epstein, D.; Khalaf, O.; Srinivasan, S.; Williamson, W.R.; Fayyazuddin, A.; Quiocho, F.A.; Hiesinger, P.R. Ca2+Calmodulin regulates SNARE assembly and spontaneous neurotransmitter release via v-ATPase subunit V0a1. J. Cell Biol. 2014, 205, 21-31. [CrossRef]

61. Portela, M.; Yang, L.; Paul, S.; Li, X.; Veraksa, A.; Parsons, L.M.; Richardson, H.E. Lgl reduces endosomal vesicle acidification and Notch signaling by promoting the interaction between Vap33 and the V-ATPase complex. Sci. Signal. 2018, 11, eaar1976. [CrossRef]

62. Abbas, Y.M.; Wu, D.; Bueler, S.A.; Robinson, C.V.; Rubinstein, J.L. Structure of V-ATPase from the mammalian brain. Science 2020, 367, 1240-1246. [CrossRef]

63. Jansen, E.J.; Scheenen, W.J.; Hafmans, T.G.; Martens, G.J. Accessory subunit Ac45 controls the V-ATPase in the regulated secretory pathway. Biochim. Biophys. Acta (BBA) Bioenerg. 2008, 1783, 2301-2310. [CrossRef] [PubMed]

64. Mazhab-Jafari, M.T.; Rohou, A.; Schmidt, C.; Bueler, S.A.; Benlekbir, S.; Robinson, C.; Rubinstein, J.L. Atomic model for the membrane-embedded VO motor of a eukaryotic V-ATPase. Nat. Cell Biol. 2016, 539, 118-122. [CrossRef]

65. Kawasaki-Nishi, S.; Nishi, T.; Forgac, M. Proton translocation driven by ATP hydrolysis in V-ATPases. FEBS Lett. 2003, 545, 76-85. [CrossRef]

66. Flannery, A.R.; Graham, L.A.; Stevens, T.H. Topological Characterization of the c, $c^{\prime}$, and $c^{\prime \prime}$ Subunits of the Vacuolar ATPase from the Yeast Saccharomyces cerevisiae. J. Biol. Chem. 2004, 279, 39856-39862. [CrossRef] [PubMed]

67. Wang, Y.; Cipriano, D.J.; Forgac, M. Arrangement of Subunits in the Proteolipid Ring of the V-ATPase. J. Biol. Chem. 2007, 282, 34058-34065. [CrossRef]

68. Kawasaki-Nishi, S.; Nishi, T.; Forgac, M. Arg-735 of the 100-kDa subunit a of the yeast V-ATPase is essential for proton translocation. Proc. Natl. Acad. Sci. USA 2001, 98, 12397-12402. [CrossRef]

69. Oot, R.A.; Kane, P.M.; Berry, E.A.; Wilkens, S. Crystal structure of yeast V1-ATPase in the autoinhibited state. EMBO J. 2016, 35, 1694-1706. [CrossRef]

70. Smardon, A.M.; Tarsio, M.; Kane, P.M. The RAVE Complex Is Essential for Stable Assembly of the Yeast V-ATPase. J. Biol. Chem. 2002, 277, 13831-13839. [CrossRef]

71. Kane, P.M. Targeting Reversible Disassembly as a Mechanism of Controlling V-ATPase Activity. Curr. Protein Pept. Sci. 2012, 13, 117-123. [CrossRef] [PubMed]

72. Sharma, S.; Oot, R.A.; Wilkens, S. MgATP hydrolysis destabilizes the interaction between subunit H and yeast V1-ATPase, highlighting H's role in V-ATPase regulation by reversible disassembly. J. Biol. Chem. 2018, 293, 10718-10730. [CrossRef] [PubMed]

73. Lu, M.; Holliday, L.S.; Zhang, L.; Dunn, W.A., Jr.; Gluck, S.L. Interaction between aldolase and vacuolar H+-ATPase: Evidence for direct coupling of glycolysis to the ATP-hydrolyzing proton pump. J. Biol. Chem. 2001, 276, 30407-30413. [CrossRef] [PubMed]

74. Lu, M.; Sautin, Y.; Holliday, L.S.; Gluck, S.L. The Glycolytic Enzyme Aldolase Mediates Assembly, Expression, and Activity of Vacuolar H+-ATPase. J. Biol. Chem. 2004, 279, 8732-8739. [CrossRef]

75. Li, M.; Zhang, C.-S.; Zong, Y.; Feng, J.-W.; Ma, T.; Hu, M.; Lin, Z.; Li, X.; Xie, C.; Wu, Y.; et al. Transient Receptor Potential V Channels Are Essential for Glucose Sensing by Aldolase and AMPK. Cell Metab. 2019, 30, 508-524. [CrossRef] [PubMed]

76. Banerjee, S.; Kane, P.M. Regulation of V-ATPase Activity and Organelle pH by Phosphatidylinositol Phosphate Lipids. Front. Cell Dev. Biol. 2020, 8, 510. [CrossRef] 
77. Fogarty, F.M.; O’Keeffe, J.; Zhadanov, A.; Papkovsky, D.; Ayllón, V.; O'Connor, R. HRG-1 enhances cancer cell invasive potential and couples glucose metabolism to cytosolic/extracellular $\mathrm{pH}$ gradient regulation by the vacuolar-H+ ATPase. Oncogene 2013, 33, 4653-4663. [CrossRef]

78. Marshansky, V.; Futai, M. The V-type H+-ATPase in vesicular trafficking: Targeting, regulation and function. Curr. Opin. Cell Biol. 2008, 20, 415-426. [CrossRef] [PubMed]

79. Qi, J.; Wang, Y.; Forgac, M. The vacuolar (H+)-ATPase: subunit arrangement and in vivo regulation. J. Bioenerg. Biomembr. 2007, 39, 423-426. [CrossRef]

80. Rahman, S.; Yamato, I.; Murata, T. Function and Regulation of Mammalian V-ATPase Isoforms. In Regulation of Ca2+-ATPases, $V$-ATPases and F-ATPases; Springer Science and Business Media LLC: Cham, Switzerland, 2016; Volume 14, pp. 283-299.

81. Lafourcade, C.; Sobo, K.; Kieffer-Jaquinod, S.; Garin, J.; Van Der Goot, F.G. Regulation of the V-ATPase along the Endocytic Pathway Occurs through Reversible Subunit Association and Membrane Localization. PLoS ONE 2008, 3, e2758. [CrossRef]

82. Esmail, S.; Kartner, N.; Yao, Y.; Kim, J.W.; Reithmeier, R.A.F.; Manolson, M.F. N-linked glycosylation of a subunit isoforms is critical for vertebrate vacuolar $\mathrm{H}(+)$-ATPase (V-ATPase) biosynthesis. J. Cell Biochem. 2018, 119, 861-875. [CrossRef]

83. Manolson, M.F.; Wu, B.; Proteau, D.; Taillon, B.E.; Roberts, B.T.; Hoyt, M.A.; Jones, E.W. STV1 gene encodes functional homologue of 95-kDa yeast vacuolar H(+)-ATPase subunit Vph1p. J. Biol. Chem. 1994, 269, 14064-14074. [CrossRef]

84. Srinivasan, S.; Vyas, N.K.; Baker, M.L.; Quiocho, F.A. Erratum to "Crystal Structure of the Cytoplasmic N-Terminal Domain of Subunit I, a Homolog of Subunit a, of V-ATPase" [J. Mol. Biol. 412/1 (2011) 14-21]. J. Mol. Biol. 2011, 413, 523. [CrossRef]

85. Kawasaki-Nishi, S.; Nishi, T.; Forgac, M.; Garofano, A.; Zwicker, K.; Kerscher, S.; Okun, P.; Brandt, U. Interacting Helical Surfaces of the Transmembrane Segments of Subunits a and $c^{\prime}$ of the Yeast V-ATPase Defined by Disulfide-mediated Cross-linking. J. Biol. Chem. 2003, 278, 41908-41913. [CrossRef]

86. Ochotny, N.; Flenniken, A.M.; Owen, C.; Voronov, I.; A Zirngibl, R.; Osborne, L.R.; E Henderson, J.; Adamson, S.L.; Rossant, J.; Manolson, M.; et al. The V-ATPase a3 subunit mutation R740S is dominant negative and results in osteopetrosis in mice. J. Bone Miner. Res. 2011, 26, 1484-1493. [CrossRef]

87. Kawasaki-Nishi, S.; Bowers, K.; Nishi, T.; Forgac, M.; Stevens, T.H. The Amino-terminal Domain of the Vacuolar Protontranslocating ATPase a Subunit Controls Targeting and in Vivo Dissociation, and the Carboxyl-terminal Domain Affects Coupling of Proton Transport and ATP Hydrolysis. J. Biol. Chem. 2001, 276, 47411-47420. [CrossRef]

88. Finnigan, G.C.; Cronan, G.E.; Park, H.J.; Srinivasan, S.; Quiocho, F.A.; Stevens, T.H. Sorting of the yeast vacuolar-type, protontranslocating ATPase enzyme complex (V-ATPase): Identification of a necessary and sufficient Golgi/endosomal retention signal in Stv1p. J. Biol. Chem. 2012, 287, 19487-194500. [CrossRef]

89. Zhang, W.; Wang, D.; Volk, E.; Bellen, H.J.; Hiesinger, P.R.; Quiocho, F.A. V-ATPase V0 sector subunit a1 in neurons is a target of calmodulin. J. Biol. Chem. 2008, 283, 294-300. [CrossRef]

90. Saw, N.M.N.; Kang, S.-Y.A.; Parsaud, L.; Han, G.A.; Jiang, T.; Grzegorczyk, K.; Surkont, M.; Sun-Wada, G.-H.; Wada, Y.; Li, L.; et al. Vacuolar H+-ATPase subunits Voa1 and Voa2 cooperatively regulate secretory vesicle acidification, transmitter uptake, and storage. Mol. Biol. Cell 2011, 22, 3394-3409. [CrossRef]

91. Matsumoto, N.; Sekiya, M.; Tohyama, K.; Ishiyama-Matsuura, E.; Sun-Wada, G.-H.; Wada, Y.; Futai, M.; Nakanishi-Matsui, M. Essential Role of the a3 Isoform of V-ATPase in Secretory Lysosome Trafficking via Rab7 Recruitment. Sci. Rep. 2018, 8, 1-18. [CrossRef]

92. Matsumoto, N.; Daido, S.; Sun-Wada, G.-H.; Wada, Y.; Futai, M.; Nakanishi-Matsui, M. Diversity of proton pumps in osteoclasts: V-ATPase with a3 and d2 isoforms is a major form in osteoclasts. Biochim. et Biophys. Acta (BBA) Bioenerg. 2014, 1837, 744-749. [CrossRef]

93. Oka, T.; Murata, Y.; Namba, M.; Yoshimizu, T.; Toyomura, T.; Yamamoto, A.; Sun-Wada, G.-H.; Hamasaki, N.; Wada, Y.; Futai, M. a4, a Unique Kidney-specific Isoform of Mouse Vacuolar H+-ATPase Subunit a. J. Biol. Chem. 2001, 276, 40050-40054. [CrossRef]

94. McGuire, C.M.; Collins, M.P.; Sun-Wada, G.; Wada, Y.; Forgac, M. Isoform-specific gene disruptions reveal a role for the V-ATPase subunit a4 isoform in the invasiveness of 4T1-12B breast cancer cells. J. Biol. Chem. 2019, 294, 11248-11258. [CrossRef]

95. Toyomura, T.; Oka, T.; Yamaguchi, C.; Wada, Y.; Futai, M. Three subunit a isoforms of mouse vacuolar H(+)-ATPase. Preferential expression of the a3 isoform during osteoclast differentiation. J. Biol. Chem. 2000, 275, 8760-8765. [CrossRef]

96. Kornak, U.; Schulz, A.; Friedrich, W.; Uhlhaas, S.; Kremens, B.; Voit, T.; Hasan, C.; Bode, U.; Jentsch, T.J.; Kubisch, C. Mutations in the a3 subunit of the vacuolar H(+)-ATPase cause infantile malignant osteopetrosis. Hum. Mol. Genet. 2000, 9, $2059-2063$. [CrossRef]

97. Zirngibl, R.A.; Wang, A.; Yao, Y.; Manolson, M.; Krueger, J.; Dupuis, L.; Mendoza-Londono, R.; Voronov, I. Novel c.G630A TCIRG1 mutation causes aberrant splicing resulting in an unusually mild form of autosomal recessive osteopetrosis. J. Cell. Biochem. 2019, 120, 17180-17193. [CrossRef]

98. Duan, X.; Yang, S.; Zhang, L.; Yang, T. V-ATPases and osteoclasts: Ambiguous future of V-ATPases inhibitors in osteoporosis. Theranostics 2018, 8, 5379-5399. [CrossRef]

99. Kartner, N.; Manolson, M.F. The Vacuolar Proton ATPase (V-ATPase): Regulation and Therapeutic Targeting. In Regulation of Ca2+-ATPases, V-ATPases and F-ATPases, 1st ed.; Chakraborti, S., Dhalla, N.S., Eds.; Springer International Publishing: Cham, Switzerland, 2016; Volume 14, pp. 407-437.

100. Nishi, T.; Kawasaki-Nishi, S.; Forgac, M. Expression and Function of the Mouse V-ATPase d Subunit Isoforms. J. Biol. Chem. 2003, 278, 46396-46402. [CrossRef] 
101. Nishi, T.; Forgac, M. Molecular Cloning and Expression of Three Isoforms of the 100-kDa a Subunit of the Mouse Vacuolar Proton-translocating ATPase. J. Biol. Chem. 2000, 275, 6824-6830. [CrossRef]

102. Crasto, G.J.; Kartner, N.; Yao, Y.; Li, K.; Bullock, L.; Datti, A.; Manolson, M.F. Luteolin inhibition of V-ATPase a3-d2 interaction decreases osteoclast resorptive activity. J. Cell Biochem. 2013, 114, 929-941. [CrossRef]

103. Lee, B.S.; Holliday, L.S.; Ojikutu, B.; Krits, I.; Gluck, S.L. Osteoclasts express the B2 isoform of vacuolar H(+)-ATPase intracellularly and on their plasma membranes. Am. J. Physiol. Physiol. 1996, 270, C382-C388. [CrossRef]

104. Smith, A.N.; Jouret, F.; Bord, S.; Borthwick, K.J.; Al-Lamki, R.S.; Wagner, C.A.; Ireland, D.C.; Cormier-Daire, V.; Frattini, A.; Villa, A.; et al. Vacuolar H+-ATPase d2 Subunit: Molecular Characterization, Developmental Regulation, and Localization to Specialized Proton Pumps in Kidney and Bone. J. Am. Soc. Nephrol. 2005, 16, 1245-1256. [CrossRef]

105. Lee, S.-H.; Rho, J.; Jeong, D.; Sul, J.-Y.; Kim, T.; Kim, N.; Kang, J.-S.; Miyamoto, T.; Suda, T.; Lee, S.-K.; et al. v-ATPase V0 subunit d2-deficient mice exhibit impaired osteoclast fusion and increased bone formation. Nat. Med. 2006, 12, 1403-1409. [CrossRef]

106. Jobst-Schwan, T.; Klämbt, V.; Tarsio, M.; Heneghan, J.F.; Majmundar, A.J.; Shril, S.; Buerger, F.; Ottlewski, I.; Shmukler, B.E.; Topaloglu, R.; et al. Whole exome sequencing identified ATP6V1C2 as a novel candidate gene for recessive distal renal tubular acidosis. Kidney Int. 2020, 97, 567-579. [CrossRef]

107. Aoto, K.; Kato, M.; Akita, T.; Nakashima, M.; Mutoh, H.; Akasaka, N.; Tohyama, J.; Nomura, Y.; Hoshino, K.; Ago, Y.; et al. ATP6V0A1 encoding the a1-subunit of the V0 domain of vacuolar H+-ATPases is essential for brain development in humans and mice. Nat. Commun. 2021, 12,1-17. [CrossRef]

108. Howaldt, A.; Nampoothiri, S.; Quell, L.-M.; Ozden, A.; Fischer-Zirnsak, B.; Collet, C.; de Vernejoul, M.-C.; Doneray, H.; Kayserili, H.; Kornak, U. Sclerosing bone dysplasias with hallmarks of dysosteosclerosis in four patients carrying mutations in SLC29A3 and TCIRG1. Bone 2019, 120, 495-503. [CrossRef]

109. Cao, W.-H.; Wei, W.-B.; Yu, G.; Li, L.; Wu, Q. Complex Heterozygous Mutation in the T-cell Immune Regulator 1 Gene Associated with Severe Ocular Characteristics of Osteopetrosis in an Infant. Chin. Med J. 2018, 131, 354-356. [CrossRef]

110. Palagano, E.; Blair, H.C.; Pangrazio, A.; Tourkova, I.; Strina, D.; Angius, A.; Cuccuru, G.; Oppo, M.; Uva, P.; Van Hul, W.; et al. Buried in the Middle but Guilty: Intronic Mutations in the TCIRG1 Gene Cause Human Autosomal Recessive Osteopetrosis. J. Bone Miner. Res. 2015, 30, 1814-1821. [CrossRef]

111. Sobacchi, C.; Pangrazio, A.; Lopez, A.G.; Gomez, D.P.; Caldana, M.E.; Susani, L.; Vezzoni, P.; Villa, A. As Little as Needed: The Extraordinary Case of a Mild Recessive Osteopetrosis Owing to a Novel Splicing Hypomorphic Mutation in the TCIRG1 Gene. J. Bone Miner. Res. 2014, 29, 1646-1650. [CrossRef]

112. Zhang, X.-Y.; He, J.-W.; Fu, W.-Z.; Wang, C.; Zhang, Z.-L. Novel mutations of TCIRG1 cause a malignant and mild phenotype of autosomal recessive osteopetrosis (ARO) in four Chinese families. Acta Pharmacol. Sin. 2017, 38, 1456-1465. [CrossRef]

113. Voronov, I.; Ochotny, N.; Jaumouillé, V.; Owen, C.; Manolson, M.F.; Aubin, J.E. The R740S mutation in the V-ATPase a3 subunit increases lysosomal $\mathrm{pH}$, impairs NFATc1 translocation, and decreases in vitro osteoclastogenesis. J. Bone Miner. Res. 2012, 28, 108-118. [CrossRef] [PubMed]

114. Bhargava, A.; Voronov, I.; Wang, Y.; Glogauer, M.; Kartner, N.; Manolson, M.F. Osteopetrosis Mutation R444L Causes Endoplasmic Reticulum Retention and Misprocessing of Vacuolar H+-ATPase a3 Subunit. J. Biol. Chem. 2012, 287, 26829-26839. [CrossRef]

115. Ochotny, N.; Van Vliet, A.; Chan, N.; Yao, Y.; Morel, M.; Kartner, N.; von Schroeder, H.P.; Heersche, J.N.M.; Manolson, M.F. Effects of Human a3 and a4 Mutations That Result in Osteopetrosis and Distal Renal Tubular Acidosis on Yeast V-ATPase Expression and Activity. J. Biol. Chem. 2006, 281, 26102-26111. [CrossRef]

116. Matsumoto, N.; Matsukawa, R.; Takahashi, S.; Kudo, K.; Sun-Wada, G.-H.; Wada, Y.; Nakanishi-Matsui, M. V-ATPase a3 isoform mutations identified in osteopetrosis patients abolish its expression and disrupt osteoclast function. Exp. Cell Res. 2020, 389, 111901. [CrossRef]

117. Matsumoto, N.; Sekiya, M.; Fujimoto, Y.; Haga, S.; Sun-Wada, G.-H.; Wada, Y.; Nakanishi-Matsui, M. Functional complementation of V-ATPase a subunit isoforms in osteoclasts. J. Biochem. 2021, 169, 459-466. [CrossRef] [PubMed]

118. Banerjee, S.; Clapp, K.; Tarsio, M.; Kane, P.M. Interaction of the late endo-lysosomal lipid PI(3,5)P2 with the Vph1 isoform of yeast V-ATPase increases its activity and cellular stress tolerance. J. Biol. Chem. 2019, 294, 9161-9171. [CrossRef] [PubMed]

119. Banerjee, S.; Kane, P.M. Direct interaction of the Golgi V-ATPase a-subunit isoform with PI(4)P drives localization of Golgi V-ATPases in yeast. Mol. Biol. Cell 2017, 28, 2518-2530. [CrossRef]

120. Vasanthakumar, T.; Bueler, S.A.; Wu, D.; Beilsten-Edmands, V.; Robinson, C.V.; Rubinstein, J.L. Structural comparison of the vacuolar and Golgi V-ATPases from Saccharomyces cerevisiae. Proc. Natl. Acad. Sci. USA 2019, 116, 7272-7277. [CrossRef]

121. Al-Bataineh, M.M.; Gong, F.; Marciszyn, A.L.; Myerburg, M.M.; Pastor-Soler, N.M. Regulation of proximal tubule vacuolar H(+)-ATPase by PKA and AMP-activated protein kinase. Am. J. Physiol. Physiol. 2014, 306, F981-F995. [CrossRef]

122. Alzamora, R.; Al-Bataineh, M.M.; Liu, W.; Gong, F.; Li, H.; Thali, R.F.; Joho-Auchli, Y.; Brunisholz, R.A.; Satlin, L.M.; Neumann, D.; et al. AMP-activated protein kinase regulates the vacuolar H+-ATPase via direct phosphorylation of the A subunit (ATP6V1A) in the kidney. Am. J. Physiol. Physiol. 2013, 305, F943-F956. [CrossRef] [PubMed]

123. Soliman, M.; Seo, J.-Y.; Kim, D.-S.; Kim, J.-Y.; Park, J.-G.; Alfajaro, M.M.; Baek, Y.-B.; Cho, E.-H.; Kwon, J.; Choi, J.-S.; et al. Activation of PI3K, Akt, and ERK during early rotavirus infection leads to V-ATPase-dependent endosomal acidification required for uncoating. PLoS Pathog. 2018, 14, e1006820. [CrossRef] 
124. Soliman, M.; Kim, D.-S.; Park, J.-G.; Kim, J.-Y.; Alfajaro, M.M.; Baek, Y.-B.; Cho, E.-H.; Park, C.-H.; Kang, M.-I.; Park, S.-I.; et al. Phosphatidylinositol 3-Kinase/Akt and MEK/ERK Signaling Pathways Facilitate Sapovirus Trafficking and Late Endosomal Acidification for Viral Uncoating in LLC-PK Cells. J. Virol. 2018, 92, 24. [CrossRef]

125. Marjuki, H.; Gornitzky, A.; Marathe, B.M.; Ilyushina, N.A.; Aldridge, J.R.; Desai, G.; Webby, R.J.; Webster, R.G. Influenza A virus-induced early activation of ERK and PI3K mediates V-ATPase-dependent intracellular $\mathrm{pH}$ change required for fusion. Cell. Microbiol. 2010, 13, 587-601. [CrossRef] [PubMed]

126. Roy, M.; Roux, S. Rab GTPases in Osteoclastic Bone Resorption and Autophagy. Int. J. Mol. Sci. 2020, 21, 7655. [CrossRef] [PubMed]

127. Stenmark, H. Rab GTPases as coordinators of vesicle traffic. Nat. Rev. Mol. Cell Biol. 2009, 10, 513-525. [CrossRef] [PubMed]

128. Hosokawa, H.; Dip, P.V.; Merkulova, M.; Bakulina, A.; Zhuang, Z.; Khatri, A.; Jian, X.; Keating, S.M.; Bueler, S.A.; Rubinstein, J.L.; et al. The $\mathrm{N}$ termini of a-subunit isoforms are involved in signaling between vacuolar H+-ATPase (V-ATPase) and cytohesin-2. J. Biol. Chem. 2013, 288, 5896-5913. [CrossRef] [PubMed]

129. Bar-Peled, L.; Schweitzer, L.D.; Zoncu, R.; Sabatini, D.M. Ragulator Is a GEF for the Rag GTPases that Signal Amino Acid Levels to mTORC1. Cell 2012, 150, 1196-1208. [CrossRef]

130. Shen, K.; Sabatini, D.M. Ragulator and SLC38A9 activate the Rag GTPases through noncanonical GEF mechanisms. Proc. Natl. Acad. Sci. USA 2018, 115, 9545-9550. [CrossRef]

131. Li, Y.-P.; Chen, W.; Liang, Y.; Li, E.; Stashenko, P. Atp6i-deficient mice exhibit severe osteopetrosis due to loss of osteoclastmediated extracellular acidification. Nat. Genet. 1999, 23, 447-451. [CrossRef]

132. Bollerslev, J.; Marks, S.C., Jr.; Pockwinse, S.; Kassem, M.; Brixen, K.; Steiniche, T.; Mosekilde, L. Ultrastructural investigations of bone resorptive cells in two types of autosomal dominant osteopetrosis. Bone 1993, 14, 865-869. [CrossRef]

133. Karsdal, M.A.; Martin, T.J.; Bollerslev, J.; Christiansen, C.; Henriksen, K. Are Nonresorbing Osteoclasts Sources of Bone Anabolic Activity? J. Bone Miner. Res. 2007, 22, 487-494. [CrossRef] [PubMed]

134. Black, D.M.; Greenspan, S.L.; Ensrud, K.E.; Palermo, L.; McGowan, J.A.; Lang, T.F.; Garnero, P.; Bouxsein, M.L.; Bilezikian, J.P.; Rosen, C.J.; et al. The effects of parathyroid hormone and alendronate alone or in combination in postmenopausal osteoporosis. N. Engl. J. Med. 2003, 349, 1207-1215. [CrossRef] [PubMed]

135. Finkelstein, J.S.; Hayes, A.; Hunzelman, J.L.; Wyland, J.J.; Lee, H.; Neer, R.M. The Effects of Parathyroid Hormone, Alendronate, or Both in Men with Osteoporosis. N. Engl. J. Med. 2003, 349, 1216-1226. [CrossRef] [PubMed]

136. Santos-Pereira, C.; Rodrigues, L.R.; Côrte-Real, M. Emerging insights on the role of V-ATPase in human diseases: Therapeutic challenges and opportunities. Med. Res. Rev. 2021, 41, 1927-1964. [CrossRef]

137. Toro, E.J.; Zuo, J.; Ostrov, D.A.; Catalfamo, D.; Bradaschia-Correa, V.; Arana-Chavez, V.; Caridad, A.R.; Neubert, J.K.; Wronski, T.J.; Wallet, S.M.; et al. Enoxacin Directly Inhibits Osteoclastogenesis without Inducing Apoptosis. J. Biol. Chem. 2012, 287, 17894-17904. [CrossRef] [PubMed]

138. Ostrov, D.A.; Magis, A.T.; Wronski, T.J.; Chan, E.K.L.; Toro, E.J.; Donatelli, R.E.; Sajek, K.; Haroun, I.N.; Nagib, M.I.; Piedrahita, A.; et al. Identification of Enoxacin as an Inhibitor of Osteoclast Formation and Bone Resorption by Structure-Based Virtual Screening. J. Med. Chem. 2009, 52, 5144-5151. [CrossRef]

139. Zhang, X.; Xu, X.; Liu, X.; Mao, C.; Qin, A.; Lu, E. Bis-enoxacin blocks alveolar bone resorption in rats with ovariectomy-induced osteoporosis. Mol. Med. Rep. 2017, 17, 3232-3238. [CrossRef] [PubMed]

140. Toro, E.; Zuo, J.; Guiterrez, A.; La Rosa, R.; Gawron, A.; Bradaschia-Correa, V.; Arana-Chavez, V.; Dolce, C.; Rivera, M.; Kesavalu, L.; et al. Bis-enoxacin Inhibits Bone Resorption and Orthodontic Tooth Movement. J. Dent. Res. 2013, 92, 925-931. [CrossRef]

141. Kartner, N.; Yao, Y.; Bhargava, A.; Manolson, M.F. Topology, glycosylation and conformational changes in the membrane domain of the vacuolar H+-ATPase a subunit. J. Cell Biochem. 2013, 114, 1474-1487. [CrossRef] [PubMed]

142. Kulshrestha, A.; Katara, G.K.; Ibrahim, S.A.; Riehl, V.E.; Schneiderman, S.; Bilal, M.; Young, A.N.; Levine, S.; Fleetwood, S.; Dolan, J.; et al. In vivo anti-V-ATPase antibody treatment delays ovarian tumor growth by increasing anti-tumor immune responses. Mol. Oncol. 2020, 14, 2436-2454. [CrossRef]

143. Kulshrestha, A.; Katara, G.K.; Ibrahim, S.; Pamarthy, S.; Jaiswal, M.K.; Sachs, A.G.; Beaman, K.D. Vacuolar ATPase 'a2' isoform exhibits distinct cell surface accumulation and modulates matrix metalloproteinase activity in ovarian cancer. Oncotarget 2015, 6, 3797-3810. [CrossRef] [PubMed]

144. Hu, Y.; Nyman, J.; Muhonen, P.; Väänanen, H.K.; Laitala-Leinonen, T. Inhibition of the osteoclast V-ATPase by small interfering RNAs. FEBS Lett. 2005, 579, 4937-4942. [CrossRef]

145. Jiang, H.; Chen, W.; Zhu, G.; Zhang, L.; Tucker, B.; Hao, L.; Feng, S.; Ci, H.; Ma, J.; Wang, L.; et al. RNAi-Mediated Silencing of Atp6i and Atp6i Haploinsufficiency Prevents Both Bone Loss and Inflammation in a Mouse Model of Periodontal Disease. PLOS ONE 2013, 8, e58599. [CrossRef]

146. Capecci, J.; Forgac, M. The Function of Vacuolar ATPase (V-ATPase) a Subunit Isoforms in Invasiveness of MCF10a and MCF10CA1a Human Breast Cancer Cells. J. Biol. Chem. 2013, 288, 32731-32741. [CrossRef]

147. Nishisho, T.; Hata, K.; Nakanishi, M.; Morita, Y.; Sun-Wada, G.-H.; Wada, Y.; Yasui, N.; Yoneda, T. The a3 Isoform Vacuolar Type H+-ATPase Promotes Distant Metastasis in the Mouse B16 Melanoma Cells. Mol. Cancer Res. 2011, 9, 845-855. [CrossRef] [PubMed] 
148. Hinton, A.; Sennoune, S.R.; Bond, S.; Fang, M.; Reuveni, M.; Sahagian, G.G.; Jay, D.; Martinez-Zaguilan, R.; Forgac, M. Function of a Subunit Isoforms of the V-ATPase in pH Homeostasis and in Vitro Invasion of MDA-MB231 Human Breast Cancer Cells. J. Biol. Chem. 2009, 284, 16400-16408. [CrossRef]

149. Flinck, M.; Hagelund, S.; Gorbatenko, A.; Severin, M.; Pedraz-Cuesta, E.; Novak, I.; Stock, C.; Pedersen, S.F. The Vacuolar H+ ATPase $\alpha 3$ Subunit Negatively Regulates Migration and Invasion of Human Pancreatic Ductal Adenocarcinoma Cells. Cells 2020, 9, 465. [CrossRef]

150. Maurizi, A.; Capulli, M.; Patel, R.; Curle, A.; Rucci, N.; Teti, A. RNA interference therapy for autosomal dominant osteopetrosis type 2. Towards the preclinical development. Bone 2018, 110, 343-354. [CrossRef]

151. Havens, M.A.; Hastings, M.L. Splice-switching antisense oligonucleotides as therapeutic drugs. Nucleic Acids Res. 2016, 44, 6549-6563. [CrossRef]

152. Couto-Vieira, J.; Nicolau-Neto, P.; Costa, E.P.; Figueira, F.F.; Simão, T.D.A.; Okorokova-Façanha, A.L.; Pinto, L.F.R.; Façanha, A.R. Multi-cancer V-ATPase molecular signatures: A distinctive balance of subunit $\mathrm{C}$ isoforms in esophageal carcinoma. EBioMedicine 2020, 51, 102581. [CrossRef] [PubMed]

153. Pangrazio, A.; Caldana, M.E.; Lo Iacono, N.; Mantero, S.; Vezzoni, P.; Villa, A.; Sobacchi, C. Autosomal recessive osteopetrosis: Report of 41 novel mutations in the TCIRG1 gene and diagnostic implications. Osteoporos. Int. 2012, 23, 2713-2718. [CrossRef]

154. Cao, W.; Wei, W.; Wu, Q. Ophthalmic phenotype of TCIRG1 gene mutations in Chinese infantile malignant osteopetrosis. BMJ Open Ophthalmol. 2018, 3, e000180. [CrossRef]

155. Barvencik, F.; Kurth, I.; Koehne, T.; Stauber, T.; Zustin, J.; Tsiakas, K.; Ludwig, C.F.; Beil, F.T.; Pestka, J.M.; Hahn, M.; et al. CLCN7andTCIRG1Mutations Differentially Affect Bone Matrix Mineralization in Osteopetrotic Individuals. J. Bone Miner. Res. 2013, 29, 982-991. [CrossRef]

156. Susani, L.; Pangrazio, A.; Sobacchi, C.; Taranta, A.; Mortier, G.; Savarirayan, R.; Villa, A.; Orchard, P.; Vezzoni, P.; Albertini, A.; et al. TCIRG1-dependent recessive osteopetrosis: Mutation analysis, functional identification of the splicing defects, andin vitro rescue by U1 snRNA. Hum. Mutat. 2004, 24, 225-235. [CrossRef]

157. Sobacchi, C.; Frattini, A.; Orchard, P.; Porras, O.; Tezcan, I.; Andolina, M.; Babul-Hirji, R.; Baric, I.; Canham, N.; Chitayat, D.; et al. The mutational spectrum of human malignant autosomal recessive osteopetrosis. Hum. Mol. Genet. 2001, 10, 1767-1773. [CrossRef] [PubMed]

158. Mazzolari, E.; Forino, C.; Razza, A.; Porta, F.; Villa, A.; Notarangelo, L.D. A single-center experience in 20 patients with infantile malignant osteopetrosis. Am. J. Hematol. 2009, 84, 473-479. [CrossRef]

159. Bahr, T.; Lund, T.; Sando, N.M.; Orchard, P.J.; Miller, W.P. Haploidentical transplantation with post-transplant cyclophosphamide following reduced-intensity conditioning for osteopetrosis: Outcomes in three children. Bone Marrow Transpl. 2016, 51, 1546-1548. [CrossRef] [PubMed]

160. Yuan, P.; Yue, Z.; Sun, L.; Huang, W.; Hu, B.; Yang, Z.; Hu, Y.; Xiao, H.; Shi, H.; Zhou, Q.; et al. Novel mutation of TCIRG1 and clinical pictures of two infantile malignant osteopetrosis patients. J. Bone Miner. Metab. 2010, 29, 251-256. [CrossRef]

161. Hernandez-Martinez, C.; Guzman-Martinez, M.N.; Scheffler-Mendoza, S.; Espinosa-Padilla, S.E.; Sobacchi, C.; Blancas-Galicia, L. [Identification of new mutations in TCIRG1 as a cause of infantile malignant osteopetrosis in two Mexican patients]. Rev. Alerg. Mex. 2018, 65, 108-116.

162. Scimeca, J.-C.; Quincey, D.; Parrinello, H.; Romatet, D.; Grosgeorge, J.; Gaudray, P.; Philip, N.; Fischer, A.; Carle, G.F. Novel mutations in theTCIRG1gene encoding the a3 subunit of the vacuolar proton pump in patients affected by infantile malignant osteopetrosis. Hum. Mutat. 2003, 21, 151-157. [CrossRef]

163. Chavez-Guitron, L.E.; Ceron-Torres, T.; Sobacchi, C.; Ochoa-Ruiz, E.; Villegas-Huesca, S. Autosomal recessive osteopetrosis type I: Description of pathogenic variant of TCIRG1 gene. Bol. Med. Hosp. Infant. Mex. 2018, 75, 255-259. [PubMed]

164. Shamriz, O.; Shaag, A.; Yaacov, B.; Eddin, A.N.; Weintraub, M.; Elpeleg, O.; Stepensky, P. The Use of Whole Exome Sequencing for the Diagnosis of Autosomal Recessive Malignant Infantile Osteopetrosis. Clin. Genet. 2016, 92, 80-85. [CrossRef]

165. Ajmal, M.; Mir, A.; Wahid, S.; Khor, C.C.; Foo, J.N.; Siddiqi, S.; Kauser, M.; Malik, S.A.; Nasir, M. Identification and in silico characterization of a novel p.P208PfsX1 mutation in V-ATPase a3 subunit associated with autosomal recessive osteopetrosis in a Pakistani family. BMC Med Genet. 2017, 18, 148. [CrossRef]

166. Al-Seraihy, A.; Al-Saedi, H.; Al-Ahmari, A.; Ghemlas, I.; Ayas, M. T-cell replete haploidentical transplantation with reduced post-transplant cyclophosphamide in six children with infantile osteopetrosis. Bone Marrow Transpl. 2021, 1-4. [CrossRef]

167. Souraty, N.; Noun, P.; Djambas-Khayat, C.; Chouery, E.; Pangrazio, A.; Villa, A.; Lefranc, G.; Frattini, A.; Mégarbané, A. Molecular study of six families originating from the Middle-East and presenting with autosomal recessive osteopetrosis. Eur. J. Med. Genet. 2007, 50, 188-199. [CrossRef]

168. Capo, V.; Penna, S.; Merelli, I.; Barcella, M.; Scala, S.; Basso-Ricci, L.; Draghici, E.; Palagano, E.; Zonari, E.; DeSantis, G.; et al. Expanded circulating hematopoietic stem/progenitor cells as novel cell source for the treatment of TCIRG1 osteopetrosis. Haematology 2020, 106, 74-86. [CrossRef] [PubMed]

169. Taranta, A.; Migliaccio, S.; Recchia, I.; Caniglia, M.; Luciani, M.; De Rossi, G.; Dionisi-Vici, C.; Pinto, R.M.; Francalanci, P.; Boldrini, R.; et al. Genotype-Phenotype Relationship in Human ATP6i-Dependent Autosomal Recessive Osteopetrosis. Am. J. Pathol. 2003, 162, 57-68. [CrossRef] 
170. Wada, K.; Harada, D.; Michigami, T.; Tachikawa, K.; Nakano, Y.; Kashiwagi, H.; Yamashita, S.; Sano, T.; Seino, Y. A case of autosomal dominant osteopetrosis type II with a novel TCIRG1 gene mutation. J. Pediatr. Endocrinol. Metab. 2013, $26,575-577$. [CrossRef]

171. Vomero, A.; Tapie, A.; Arroyo, C.; Raggio, V.; Peluffo, G.; Dufort, G. Malignant Infantile osteopetrosis. Rev. Chil. Pediatr. 2019, 90, 443-447. [CrossRef]

172. Bliznetz, E.A.; Tverskaya, S.M.; A Zinchenko, R.; Abrukova, A.V.; Savaskina, E.N.; Nikulin, M.V.; Kirillov, A.G.; Ginter, E.K.; Polyakov, A.V. Genetic analysis of autosomal recessive osteopetrosis in Chuvashiya: The unique splice site mutation in TCIRG1 gene spread by the founder effect. Eur. J. Hum. Genet. 2009, 17, 664-672. [CrossRef]

173. Michigami, T.; Kageyama, T.; Satomura, K.; Shima, M.; Yamaoka, K.; Nakayama, M.; Ozono, K. Novel mutations in the a3 subunit of vacuolar $\mathrm{H}+$-adenosine triphosphatase in a Japanese patient with infantile malignant osteopetrosis. Bone 2002, 30, 436-439. [CrossRef]

174. Yu, T.; Yu, Y.; Wang, J.; Yin, L.; Zhou, Y.; Ying, D.; Huang, R.; Chen, H.; Wu, S.; Shen, Y.; et al. Identification of TCIRG1 and CLCN7 gene mutations in a patient with autosomal recessive osteopetrosis. Mol. Med. Rep. 2014, 9, 1191-1196. [CrossRef]

175. Siddaiahgari, S.R.; Makadia, D.; Shah, N.; Devi, R.R.; Lingappa, L. Identification of Novel Mutation in Autosomal Recessive Infantile Malignant Osteopetrosis. Indian J. Pediatr. 2013, 81, 969-970. [CrossRef]

176. Palagano, E.; Susani, L.; Menale, C.; Ramenghi, U.; Berger, M.; Uva, P.; Oppo, M.; Vezzoni, P.; Villa, A.; Sobacchi, C. Synonymous Mutations Add a Layer of Complexity in the Diagnosis of Human Osteopetrosis. J. Bone Miner. Res. 2016, 32, 99-105. [CrossRef]

177. Del Fattore, A.; Peruzzi, B.; Rucci, N.; Recchia, I.; Cappariello, A.; Longo, M.; Fortunati, D.; Ballanti, P.; Iacobini, M.; Luciani, M.; et al. Clinical, genetic, and cellular analysis of 49 osteopetrotic patients: Implications for diagnosis and treatment. J. Med Genet. 2005, 43, 315-325. [CrossRef] [PubMed]

178. Gheorghe, G.; Galambos, C.; Jain, S.; Krishnamurti, L.; Jaffe, R. A Novel TCIRG1 Gene Mutation Leads to Severe Osteopetrosis with Altered Content of Monocytes/Macrophages in Several Organs. Pediatr. Dev. Pathol. 2012, 15, 156-159. [CrossRef]

179. Engiz, O.; Kara, S.; Bagrul, D.; Lahr, G.; Alioglu, B.; Bilge, Y.D.; Arikan, I. Infantile malignant osteopetrosis: A rare cause of neonatal hypocalcemia. J. Pediatr. Endocrinol. Metab. 2012, 25, 1205-1207. [CrossRef]

180. Lanzi, G.; Ferraro, R.M.; Masneri, S.; Piovani, G.; Barisani, C.; Sobacchi, C.; Villa, A.; Vezzoni, P.; Giliani, S. Generation of 3 clones of induced pluripotent stem cells (iPSCs) from a patient affected by Autosomal Recessive Osteopetrosis due to mutations in TCIRG1 gene. Stem Cell Res. 2020, 42, 101660. [CrossRef]

181. Chen, W.; Twaroski, K.; Eide, C.; Riddle, M.J.; Orchard, P.J.; Tolar, J. TCIRG1 Transgenic Rescue of Osteoclast Function Using Induced Pluripotent Stem Cells Derived from Patients with Infantile Malignant Autosomal Recessive Osteopetrosis. J. Bone Jt. Surg. Am. Vol. 2019, 101, 1939-1947. [CrossRef] [PubMed]

182. Phadke, S.R.; Fischer, B.; Gupta, N.; Ranganath, P.; Kabra, M.; Kornak, U. Novel mutations in Indian patients with autosomal recessive infantile malignant osteopetrosis. Indian J. Med Res. 2010, 131, 508-514.

183. Demir, K.; Nalbantoğlu, Ö.; Karaer, K.; Korkmaz, H.A.; Yıldız, M.; Tunç, S.; Özkan, B. Genetic Diagnosis Using Whole Exome Analysis in Two Cases with Malignant Osteopetrosis of Infancy. J. Clin. Res. Pediatr. Endocrinol. 2015, 7, 356-357. [CrossRef] [PubMed] 